Chapman University

Chapman University Digital Commons

Pharmacy Faculty Articles and Research

School of Pharmacy

2017

\title{
Engineered Peptides for Applications in Cancer- Targeted Drug Delivery and Tumor Detection
}

R. Soudy

University of Alberta

N. Byeon

University of Alberta

Y. Raghuwanshi

University of Alberta

S.Ahmed

University of Alberta

A. Lavasanifar

University of Alberta

See next page for additional authors

Follow this and additional works at: https://digitalcommons.chapman.edu/pharmacy_articles

Part of the Amino Acids, Peptides, and Proteins Commons, Cancer Biology Commons, Chemical Actions and Uses Commons, Medicinal and Pharmaceutical Chemistry Commons, Other Pharmacy and Pharmaceutical Sciences Commons, and the Pharmaceutics and Drug Design Commons

\section{Recommended Citation}

Soudy R, Byeon N, Raghuwanshi Y, Ahmed S, Lavasanifar A, Kaur K. Engineered peptides for applications in cancer-targeted drug delivery and tumor detection. Mini Rev Med Chem.. 2017;17(18):1696-1712. doi: 10.2174/1389557516666160219121836

This Article is brought to you for free and open access by the School of Pharmacy at Chapman University Digital Commons. It has been accepted for inclusion in Pharmacy Faculty Articles and Research by an authorized administrator of Chapman University Digital Commons. For more information, 


\section{Engineered Peptides for Applications in Cancer-Targeted Drug Delivery and Tumor Detection}

\section{Comments}

This is a pre-copy-editing, author-produced PDF of an article accepted for publication in Mini-Reviews in Medicinal Chemistry, volume 17, issue 18, in 2017 following peer review. The definitive publisherauthenticated version is available online at DOI: 10.2174/1389557516666160219121836.

\section{Copyright}

Bentham Science Publishers

\section{Authors}

R. Soudy, N. Byeon, Y. Raghuwanshi, S. Ahmed, A. Lavasanifar, and Kamaljit Kaur 


\section{Engineered Peptides for Applications in Cancer-}

\section{Targeted Drug Delivery and Tumor Detection}

R. Soudy ${ }^{1,2}$, N. Byeon ${ }^{1}$, Y. Raghuwanshi ${ }^{1}$, S. Ahmed ${ }^{1,3}$, A. Lavasanifar ${ }^{1,4}$ and K. Kaur ${ }^{*, 1,5}$

${ }^{1}$ Faculty of Pharmacy and Pharmaceutical Sciences, University of Alberta, Edmonton, Alberta, T6G 2E1, Canada

${ }^{2}$ Faculty of Pharmacy, Cairo University, Cairo, Egypt

3 Department of Pharmacognosy and Medicinal Chemistry, Faculty of Pharmacy, Taibah University, Al-Madinah Al-munawarah 41477, Kingdom of Saudi Arabia

${ }^{4}$ Department of Chemical and Material Engineering, University of Alberta, Edmonton, Alberta, T6G 2V4, Canada

${ }^{5}$ Chapman University School of Pharmacy (CUSP), Harry and Diane Rinker Health Science Campus, Chapman University, Irvine, CA, 92618-1908, USA

Corresponding Author

Tel. 714-516-5494

email.kkaur@chapman.edu 


\begin{abstract}
Cancer-targeting peptides as ligands for targeted delivery of anticancer drugs or drug carriers have the potential to significantly enhance the selectivity and the therapeutic benefit of current chemotherapeutic agents. Identification of tumor-specific biomarkers like integrins, aminopeptidase $\mathrm{N}$, and epidermal growth factor receptor as well as the popularity of phage display techniques along with synthetic combinatorial methods used for peptide design and structure optimization have fueled the advancement and application of peptide ligands for targeted drug delivery and tumor detection in cancer treatment, detection and guided therapy. Although considerable preclinical data have shown remarkable success in the use of tumor targeting peptides, peptides generally suffer from poor pharmacokinetics, enzymatic instability, and weak receptor affinity, and they need further structural modification before successful translation to clinics is possible. The current review gives an overview of the different engineering strategies that have been developed for peptide structure optimization to confer selectivity and stability. We also provide an update on the methods used for peptide ligand identification, and peptide-receptor interactions. Additionally, some applications for the use of peptides in targeted delivery of chemotherapeutics and diagnostics over the past 5 years are summarized.
\end{abstract}

Keywords:

Cancer Targeting Peptides; Phage Display; Spot Synthesis; Integrins; Aminopeptidase N; Targeted drug delivery; Tumor imaging 


\section{INTRODUCTION}

A wide array of strategies have been developed over the past two decades to enhance the selective delivery of chemotherapeutic drugs to the tumor site, reduce their toxicity, and overcome the emergence of multidrug resistance in tumors $[1,2]$. One avenue to accomplish this feat is the targeted delivery of therapeutic molecules to the tumor cells, or tumor microenvironments via ligands that are specific for tumor-expressed markers or receptors. By studying the distinct nature of the tumor tissue and its microenvironment researchers have discovered that tumor cells express various biomarkers that normal cells do not express or express at a much lower level [3]. These markers are mostly proteinous in nature. Identification and characterization of ligands with high affinity for these markers can lead to selective accumulation of cytotoxic molecules at the tumor site [4]. In this regard, different ligands have been identified and studied for tumor selective drug targeting, such as antibodies, peptides, aptamers, affibodies, hormones and low molecular weight compounds, such as folate and some vitamins. These ligands allow specific delivery of drugs to cancer cells either via direct chemical conjugation, or indirectly by their conjugation to the surface of different drug delivery systems, such as liposomes and micelles.

In recent years, peptides and peptidomimetics have gained attention as an alternative to popular antibodies and affibodies as cancer targeting ligands. Peptide-based therapeutics offer multiple advantages. Their small size allows easy penetration into deep tissues, they can be less immunogenic, and they can be synthesized easily using automated solid phase methodology, allowing rapid synthesis with good yields and in a cost effective manner. Peptide conjugation to different cargos is much easier and more reproducible than conjugation with large proteins. Moreover, peptides display higher stability during different storage conditions [5]. 
Peptides suffer from some disadvantages, such as poor enzymatic stability, difficulty maintaining secondary structure, and fast renal clearance. In this review, we summarize recent strategies for developing peptide analogs with enhanced biological and pharmacokinetic properties through the design and optimization of various tumor targeting peptide ligands. These strategies can help in translating cancer-targeted peptide ligands to clinical settings. We focus on three potential molecular markers in tumor targeting research, namely, integrins, aminopeptidase $\mathrm{N}$, and human epidermal growth factor. Finally, some of the recent studies for applications of tumor targeting peptides in cancer-targeted therapeutics and in tumor diagnostics are presented.

\section{TARGETS IN SOLID TUMORS}

Several receptors that are overexpressed in the tumor environment and less expressed in normal (non-cancerous) tissues have been identified [6,7]. In this section, we will discuss three distinct molecular markers for tumor targeting.

\section{INTEGRINS}

Integrins are heterodimeric membrane glycoproteins that are composed of non-covalently attached $\alpha$ - and $\beta$ - subunits. The different combinations of $\alpha$ - and $\beta$-subunits (24 distinct heterodimers) account for the ligand binding specificity and signaling pathway of each integrin. Integrins are cell adhesion receptors for extracellular matrix proteins, growth factors, cytokines, and immunoglobulins. When integrins bind to their extracellular ligands a signaling cascade that regulates cell differentiation, proliferation, apoptosis and migration is induced $[8,9]$. Some subtypes of integrins such as $\alpha v \beta 3$, $\alpha v \beta 5$, and $\alpha 5 \beta 1$ are over-expressed on cancer cells, and they 
are found to have diverse roles in different stages of cancer, including tumor growth, invasion, angiogenesis, cancer cell transformation, and metastasis. Particularly, $\alpha v \beta 3$ integrin subtype that is upregulated on angiogenic endothelial cells and on various tumor cell lines plays a major role in angiogenesis, tumor neovascularization, and tumor metastasis [7]. The angiogenic pathway is induced by fibroblast growth factor (b-FGF) or tumor necrosis factor alpha (TNF- $\alpha$ ). The integrin $\alpha v \beta 5$ is involved in angiogenesis as well, but through a pathway stimulated by vascular endothelial growth factor (VEGF) or transforming growth factor alpha (TGF- $\alpha$ ). Studies have reported that integrins recognize the extracelluar matrix proteins through the RGD (Arg-GlyAsp) peptide sequence found in the native ligands such as fibronectin, vitronectin, plasminogen, prothrombin, laminin, and osteopontin $[10,11]$. Peptides or peptidomimetics containing the RGD motif efficiently block these integrin-ligand interactions, and are therefore being extensively applied for cancer-targeted therapeutics and in tumor diagnostics $[12,13]$.

\section{AMINOPEPTIDASE N}

Aminopeptidase $\mathrm{N}(\mathrm{APN})$ or CD13 is a $\mathrm{Zn}^{2+}$ dependent integral membrane enzyme present in a number of human organs, tissues and cell types, such as endothelial cells, epithelial cells, fibroblasts, and leukocytes $[14,15]$. APN is described as a multi-functional protein as it catalyzes the cleavage of neutral amino acids from the N-terminal end of the peptides, [16] as well as plays a role in some cell functionalities including antigen presentation, angiogenesis, tumor cell invasion, and metastasis. It also plays key role in physiologically important processes such as protein maturation, degradation of peptides, and cell cycle control [17]. Specific APN isoforms are highly expressed in various tumors, such as head and neck squamous-cell carcinoma, acute myloid leukemia, prostate cancer and colon cancer. Besides, APN is expressed on angiogenic blood vessels, and the isoforms in angiogenic vessels are different from the APN 
forms expressed by the endothelium of normal blood vessels [18]. Reports have shown that tripeptide NGR (Asn-Gly-Arg) can specifically bind APN, and therefore NGR is gaining popularity as an efficient ligand for developing peptide-based delivery system targeting tumors.

\section{HUMAN EPIDERMAL GROWTH FACTOR RECEPTOR}

Epidermal growth factor receptor (EGFR) is a glycoprotein consisting of an extracellular Nterminal binding domain, a hydrophobic transmembrane region and an intracellular $\mathrm{C}$-terminal tyrosine kinase (TK) domain. EGFR belongs to a family of receptors consisting of four different types of proteins (EGFR, ErbB-2, ErbB-3, and ErbB-4) that are activated following binding to their ligands which include epidermal growth factor (EGF), transforming growth factor- $\alpha$ (TGF $\alpha$ ), amphiregulin, heparin-binding EGF-like growth factor, betacellulin, and epiregulin [19, 20]. A signal that hits an individual receptor activates various signaling pathways that promote different cell processes such as, proliferation, angiogenesis, tumor survival, and metastasis. EGFR activation normally leads to cellular growth and its signaling can provide substantial advantages in tumor cells' survival, therefore, specific EGFR inhibition is one of the key strategies in cancer therapy [21]. EGFR receptor overexpression has been implicated in different types of human cancers, and it has been involved in cancer progression and poor prognosis. Numerous EGFR blockers have been investigated which include anti-EGFR monoclonal antibodies, such as cetuximab (clinically approved), antibody-drug conjugates, and antisense oligonucleotides. In addition to direct EGFR-inhibition therapies, significant research utilized EGFR-binding ligands for conjugation on different nanosystems surfaces to achieve specific tumor drug delivery and internalization. Small peptides such as YHWYGYTPQNVI (GE11) and LARLLT have been identified as effective ligands for drug carriers for EGFR targeting [22, 23]. 


\section{METHODS FOR DISCOVERY OF HIGHLY SPECIFIC TUMOR TARGETING PEPTIDES}

Peptides that target cancer have been discovered by the rational design approach or random combinatorial methods. The rational design approach involves selection of an endogenous peptide sequence that interacts with a specific receptor, followed by structural optimization using standard synthetic methods such as alanine scan, D-amino acid scan, and truncation of N- and Cterminal residues to identify receptor binding regions. The minimal sequence identified is then used in different peptide-receptor targeting strategies. Peptides identified by the rational design approach are octreotide against somatostatin receptor, [24] bombesin against bombesin receptor, [25] and bradykinin analogues against bradykinin receptor [26]. In contrast, combinatorial peptide libraries enable the discovery of high-affinity peptide ligands to a vast number of receptors including ones that have unknown endogenous ligands by random peptide sequence search. The most common combinatorial peptide library methods (phage display, one-bead one compound (OBOC) combinatorial bead library, [27, 28] and SPOT synthesis [29]) are discussed below. The sequences identified by library methods are also subjected to structural optimization to make them fit for therapeutic use.

PHAGE DISPLAY. A phage display library is created by preparing a random mixture of phage clones with each displaying a single peptide on its surface. The library is then exposed to intact cell or a protein target of interest present on a solid support (in vitro) or directly in mice (in vivo) [30]. Following this, the cells or the protein are collected, washed to elute all non-bound phages, and then amplified to produce the hit peptide for encoding the peptide sequence. The screening of phage display peptide libraries has been reported in cancer patients as well $[31,32]$. This technique allows peptide selection without any knowledge of the receptor, facilitating the 
development of targeted therapies. In general, the phage display method has shown great success in generating multiple lead peptides for the development of tumor-targeted therapeutics $[33,34]$.

ONE-BEAD-ONE-COMPOUND LIBRARY. The one-bead-one-compound (OBOC) combinatorial bead library is a synthetic method for generating combinatorial libraries [28]. This method involves creation of an entirely random library on a polymer support, such as Tentagel, using split mix synthesis. The library is created by dividing the resin beads into a number of equal portions, with each portion having a single amino acid coupled to it. After reaction completion, all the resin beads are combined, thoroughly mixed, and once again divided equally followed by coupling of the second amino acid. The steps are repeated until the desired peptide length is reached. This method allows inclusion of unnatural amino acids in the sequence, and it has been utilized in the discovery of many cancer targeting peptides [35, 36].

SPOT SYNTHESIS. SPOT synthesis on functionalized cellulose membranes allows the creation of a random new library or a library based on the lead peptide sequence identified using the aforementioned methods. The library is synthesized on the membrane in the form of peptide array, using SPOT synthesis, which is then screened against purified protein or intact cells to identify peptides with specific binding affinity for the protein or the cell line [37]. Ahmed et al. developed a peptide array library based on the lead peptide sequence p160 (12-mer peptide identified by phage display) to screen for peptides with specific and high affinity for breast cancer cell lines [38]. Similarly, screening of NGR peptides using a synthetic peptide array library on cellulose membrane led to the identification of peptides with high and specific binding for APN (CD13+) expressing cancer cells [39]. 


\section{TUMOR TARGETING PEPTIDES}

Currently, the peptide tumor-targeted therapies follow two main strategies: i) targeting of tumor cells, via tumor associated antigens, specifically expressed or overexpressed by tumor cells, and ii) targeting of tumor vasculature via vascular overexpressed antigens. The goal of the first strategy is the selective targeted delivery of cytotoxic moieties to cancer cells, with the consequent death of tumor cells and low or no damage to healthy tissues. In the second strategy, the goal is to target tumor vessels and impair them through inhibition of pro-angiogenic growth factors, which produces tumor starvation and reduced tumor cell access to the blood stream causing reduced metastasis. A full database of tumor homing peptides was recently published [40]. The selective delivery of therapeutics such as radionuclides, cytotoxic entities, and other agents to tumors using peptide ligands is an extremely effective targeting approach, and holds great promise in cancer therapy and diagnosis [41]. While it is not feasible to discuss all potential cancer targeting peptides discovered so far, here we focus on some of the potential peptide sequences which had their in vivo targeting capacity evaluated (Table 1).

\section{TUMOR CELL SURFACE RECEPTOR TARGETING PEPTIDES}

Tumor targeting peptides that bind proteins involved in biological functions such as cell surface receptors, growth factor receptors and cell adhesion molecules are exploited for targeting a variety of cancers. These peptides have been identified using phage display; therefore, in some cases the specific receptor is not yet known. 
Table 1. Tumor targeting peptides isolated by in vivo biopanning

\begin{tabular}{|c|c|c|}
\hline Cancer Type & Peptide Sequence (Name) & Receptor \\
\hline \multicolumn{3}{|l|}{ Tumor Specific } \\
\hline \multirow[t]{3}{*}{ Breast } & VPWMEPAYQRFL (p160) & - \\
\hline & CRKRLDRN (AP1) & IL-4R \\
\hline & SMDPFLFQLLQL (SP90) & - \\
\hline Prostate & FRPNRAQDYNTN (DUP-1) & - \\
\hline \multirow[t]{3}{*}{ Hepatocarcinoma } & YHWYGYTPQNVI (GE11) & hEGFR \\
\hline & TACHQHVRMVRP (WP05) & - \\
\hline & AGKGTPSLETTP (A54) & - \\
\hline \multirow[t]{2}{*}{ Pancreatic } & Penetratin sequence conjugated G7-18NATE & Grb7 \\
\hline & SHGFSRHSMTLI (PA1) & - \\
\hline Gastric & SWKLPPS & - \\
\hline \multicolumn{3}{|l|}{ Tumor Vasculature } \\
\hline \multirow[t]{2}{*}{ Tumor angiogenic vessels } & CDCRGDCFC (RGD-4C) & Integrins \\
\hline & CNGRCVSGCAGRC (NGR) & APN \\
\hline Tumor lymphatic vessels & CGNKRTRGC (LyP-1) & p32/gC1qR \\
\hline $\begin{array}{l}\text { The selection method for al } \\
\text { LyP-1 where ex vivo/in viv }\end{array}$ & $\begin{array}{l}\text { e peptides was phage display mouse xenograf } \\
\text { creen on mouse xenograft was used. Grb7; g } \\
\text {; Aminopeptidase N, -; not determined. }\end{array}$ & $\begin{array}{l}\text { except for } \\
\text { owth factor }\end{array}$ \\
\hline
\end{tabular}

BREAST CANCER. Screening using an in vitro phage-display peptide library against WAC2 neuroblastoma cells yielded a linear peptide p160 (Fig. 1) [42]. It was found that p160 internalizes into MDA-MB-435 cells, and clusters at the cellular membrane. ${ }^{131}$ I-labeled p160 intravenously injected in mice specifically accumulated in the breast tumor xenografts compared to heart, liver, spleen, and brain, and the tissue perfusion of the mice decreased the radioactivity in nonspecific tissue [43]. Ahmed et al. used a peptide array-cell binding assay to identify better 
analogues of p160. Using a synthetic peptide array of 70 linear peptide sequences based on p160 peptide as a lead, a 10-mer p160 analogue (peptide 18, Fig. 1) that displayed 3-fold better binding compared to p160 for the MDA-MB-435 and MCF-7 cancer cells was identified [38]. To understand the structural basis for the enhanced binding of peptide 18 compared to $\mathrm{p} 160$, the NMR solution structures of p160 and 18 in trifluoroethanol was elucidated, and showed that peptide 18 is more helical than p160 (Fig. 1C) [44]. The helical structure and the presence of distinct binding faces supported the better performance of peptide 18. Peptide p160 analogue (peptide 18) was further optimized for improved binding and proteolytic stability to yield 10-mer peptide 18-4 (Fig. 1B) with two D-amino acid residues [44]. Peptide 18-4 maintained proteolytic stability in the presence of human serum and liver homogenate from mice and displayed up to 3.5-fold enhanced binding to cancer cells compared to p160 peptide analogue 18 [44].

Peptide AP1 (CRKRLDRN) is another breast homing peptide identified using phage display that selectively binds to the interleukin 4 receptor (IL-4R). Interleukin binding to the IL-4R receptor increases the expression of anti-apoptotic proteins such as cFLIP/CFLAR, PED/PEA15 and Bcl (BCL family proteins) which counteracts the ability of cancer drugs to cause cell death. Therefore, targeting the IL-4R receptor enhances the therapeutic efficacy of anticancer drugs [45]. The targeting ability of AP1 peptide was assessed in vitro using a genetically expressed library of elastin like polypeptide (ELP) polymers containing different number of tumor targeting AP1 peptide in cancer cells. The results showed that the fluorescently labeled ELP polymer containing six AP1 peptides enhanced tumor-specific targeting and the uptake efficiency in MDA-MB-231 breast cancer cell lines. Fluorescence images using near-infrared fluorescence (NIRF) live 
(A)

$1^{\text {st }}$ Generation

VPWMEPAYQRFL p160

$2^{\text {nd }}$ Generation

WXEAAYQREL 18

WXEAAYQREL $\quad 18-4$

(B)

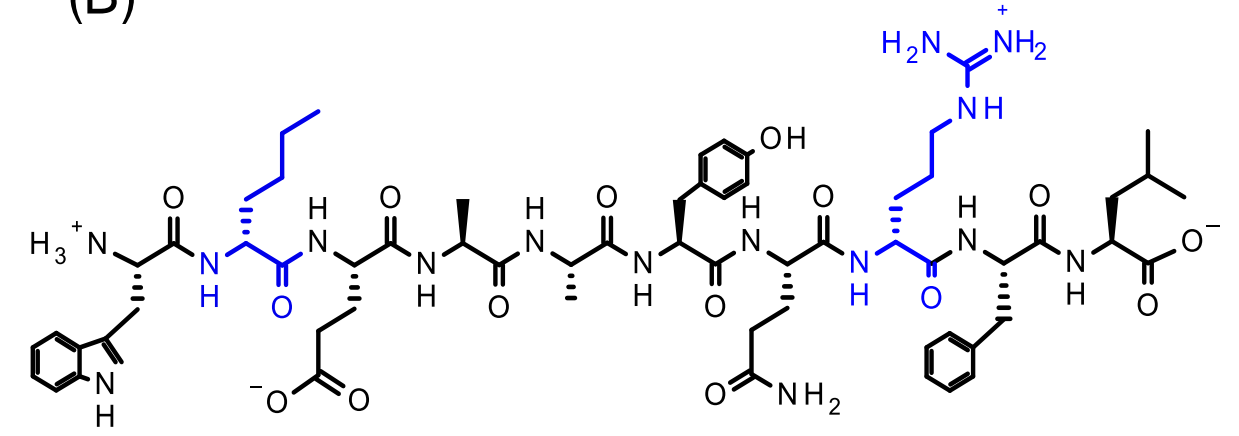

18-4

(C)
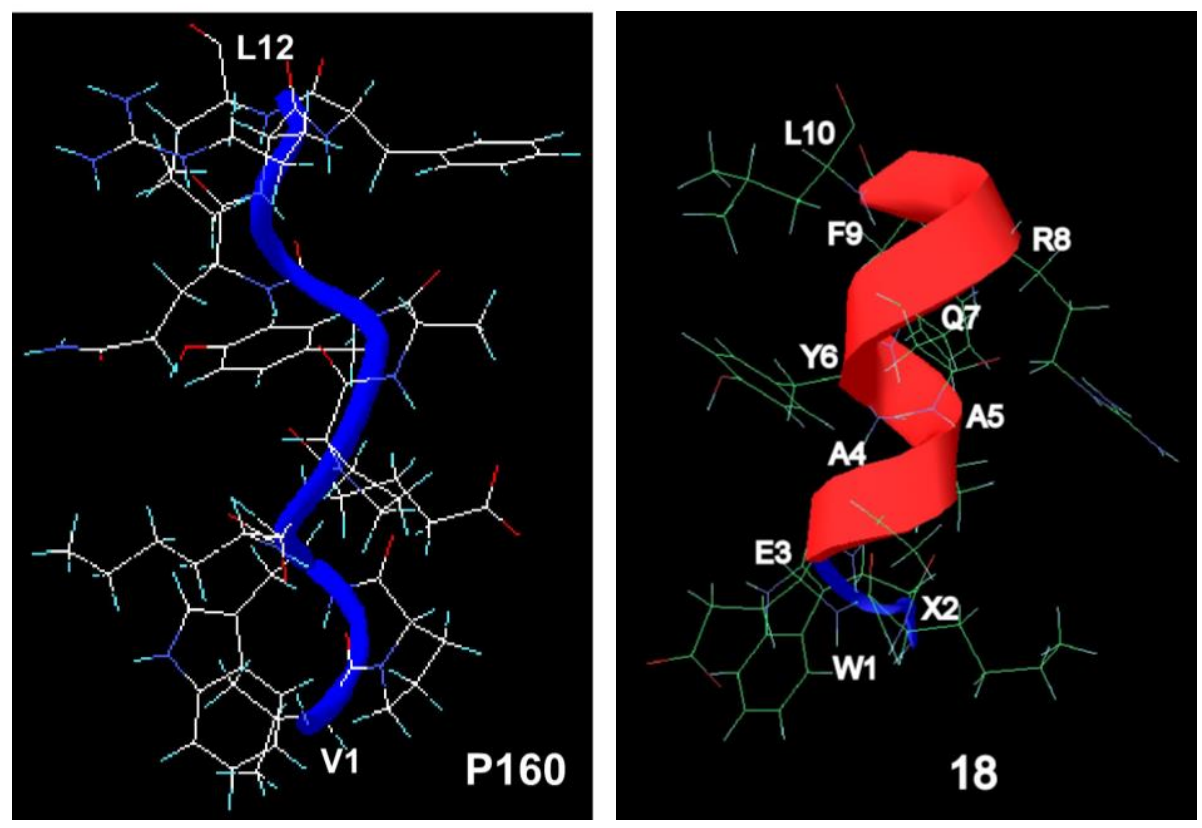

Fig. (1). (A) Sequence of first generation p160 peptide and the second generation engineered p160 analogues, namely 18 and 18-4. (B) Chemical structure of peptide 18-4. Peptide 18-4 contains two D-amino acids (blue) and $\mathrm{x}$ is norleucine (Nle). (C) The three dimensional NMR solution structures of p160 (left) and 18 (right) in 2,2,2,-trifluoroethanol (TFE). 
optical imaging in MDA-MB-231 breast cancer-bearing mice showed that the [AP1-V12]6 polymer accumulated in tumors after $10 \mathrm{~min}$ from intravenous injection, peaked after $6 \mathrm{~h}$, and was maintained up to $24 \mathrm{~h}$. Biodistribution studies showed that [AP1-V12]6 fluorescence intensity was higher in the target tumor with negligible fluorescence in off-target organs, including the lung, spleen, and heart [45].

A 12-mer peptide, SP90 (SMDPFLFQLLQL), identified using biopanning against BT483 breast cancer cells binds specifically to different breast cancer cell lines such as MDA-MB-231, MCF7, BT483, SK-BR-3, and MDA-MB-361. Using mice bearing BT483-derived tumor xenografts, it was found that PC90 (phage carrying SP90 peptide) selectively accumulated in tumor tissue compared to control tissues. Moreover, when PC90 was co-injected with the SP90 peptide, it competitively inhibited PC90 binding to the tumor tissue [46]. PEGylated liposomal doxorubicin decorated with SP90 peptide (SP90-LD) decreased tumor volume by 2.3 -fold compared to liposomal doxorubicin (LD) in SCID mice bearing BT483-derived xenografts. No detectable reduction in body weight or WBC count was observed in SP90-LD group compared to the LD group [46].

PROSTATE CARCINOMA. Zitzmann et al. used a 12-mer phage-display peptide library to screen for ligands for the DU-145 prostate carcinoma cell line [47]. After six rounds of selection, all sequenced phage clones displayed the same peptide called DUP-1 (FRPNRAQDYNTN). Synthetic DUP-1 peptide bound and internalized in prostate carcinoma DU-145 and PC-3 cells with the highest binding rate after 5 minutes, but not in normal HUVEC or the normal prostate cell line PNT-2. In vivo results showed that DUP-1 peptide accumulated specifically in DU-145 and PC-3 xenografts, and perfusion decreased the non-specific accumulation in tissues such as 
blood and kidney. In vivo biodistribution in the AT-1 rat prostate adenocarcinoma model showed that DUP-1 accumulated in prostate tumor tissue three times more compared to normal prostate tissue. DUP-1 degraded in human, mouse and rat serum within $10 \mathrm{~min}$. In a subsequent study, the peptide structure was optimized to increase its stability in vivo [48].

HEPATOCELLULAR CARCINOMA. In vitro phage-display peptide library screening against recombinant human epidermal growth factor receptor (hEGFR) led to the identification of peptide GE11 (YHWYGYTPQNVI).[49] Synthetic free GE11 peptide and EGF inhibited phage binding to hEGFR, as well as the EGFR-positive human hepatocarcinoma cell line SMMC-7721 with binding affinity $(\mathrm{Kd})$ of $22.3 \mathrm{nM}$. These results revealed the binding specificity of GE11 peptide for EGFR and the overlap of EGF and GE11 binding sites. Intravenous injection of 125I-labeled GE11 in mice specifically accumulated in SMMC-7721 tumor in mouse xenografts, and the radioactivity in tumor was reduced by 4.5 -fold at $4 \mathrm{~h}$ postinjection when excess unlabeled peptide was coinjected with the labeled peptide. The same study further demonstrated that GE11-coated PEI/DNA polyplexes could target mice bearing subcutaneous SMMC-7721 tumors in vivo, and caused an 18-fold increase in luciferase expression in the tumor compared with non-coated PEI/DNA polyplexes. When the gPEI/DNA was coinjected with free GE11 peptide, the gene expression decreased by 5-fold [49].

In another study, Du et al. screened a phage-displayed peptide library in vitro against the human hepatocellular carcinoma cell line BEL-7402 [50]. Phage bearing TACHQHVRMVRP (WP05) peptide bound specifically to BEL-7402 cells. FAM-Labeled WP05 peptide bound to four kinds of liver cancer cell lines (BEL-7402, BEL-7404, SMMC-7721, and HepG2), but not the normal liver cell line as shown by using fluorescence microscopy and flow cytometry. WP05 phage 
injected intravenously into mice bearing BEL-7402 tumors accumulated specifically in the tumor as compared to normal mouse liver tissue.

Peptide A54 (AGKGTPSLETTP), identified using in vivo phage-display against hepatoma cell line BEL-7402, was conjugated to micelle surfaces and A54-PEG-CS-SA micelles were retained primarily by the tumor xenografts in BEL-7402 human hepatoma nude bearing mice. Further, the targeting ability of A54 micelles carrying Dox was supported by tumor inhibition by 86\% in the A54-PEG-CS-SA/Dox treated group compared to $74 \%$ in the Dox treated group. Formulation A54-PEG-CS-SA/DOX displayed reduced toxicity, mostly likely due to high targeting efficiency and reduction of heart distribution [51].

PANCREATIC CANCER. Pancreatic cancer specimens show higher levels of growth factor receptor-bound protein 7 (Grb7) than their corresponding normal pancreatic tissue specimens, and this higher expression level is correlated with lymph node metastasis [52]. Pero et al. demonstrated that Grb7 siRNA abrogated Grb7 expression and resulted in reduced pancreatic cancer cell migration into fibronectin. A non-phosphorylated peptide inhibitor of Grb7 SH2 domain, G7-18NATE, which was previously identified using phage display technology, was conjugated to a penetratin sequence for targeting and internalization into human pancreatic cancer cells (Panc-1) for evaluation of metastasis inhibition [53]. Treatment of cells with the peptide conjugate did not alter proliferation, but it did reduce migration into fibronectin. In vivo, BALB/c mice injected intraperitoneally with Panc-1 cells followed by Grb7 peptide inhibitor over 2 weeks showed drastically limited pancreatic tumor cell migration and metastases. Another phage screening against irradiated Capan-2 human pancreatic adenocarcinoma cells led to the identification of peptide PA1 (SHGFSRHSMTLI) [54]. Peptide PA1 was internalized into 
irradiated Capan-2 cells but not into non-irradiated cells, and intraperitoneally injected PA1 targeted subcutaneous xenografts of irradiated Capan-2 tumors in mice, but not in non-irradiated xenografts.

GASTRIC CANCER. Akita et al. identified a tri-peptide motif, KLP, through a phagedisplayed peptide library against peritoneal tumors of gastric cancer in BALB/nu mouse xenografts [55]. After intraperitoneal injection into mice, phage displaying the KLP peptide displayed a 64-fold increase in binding to peritoneal tumors compared to control phage, and were primarily accumulated in tumors rather than in normal organs. Synthesized peptide with the KLP motif (SWKLPPS) also showed a strong binding to peritoneal tumors and SWKLPPS-decorated liposomes accumulated in the peritoneal metastases more efficiently than non-coated liposomes. Furthermore, treatment with liposomes conjugated with SWKLPPS loaded with Dox accumulated more in tumors and also enhanced the anti-proliferative effects of Dox compared to non-targeted control liposomes.

\section{VASCULAR TARGETING PEPTIDES}

Molecular, structural, and functional studies have revealed extensive differences between normal vasculature and tumor blood vessels, which can be used in selective tumor targeting. Tumor blood vessels were shown to be leaky and circuitous [56]. In addition, angiogenic tumor blood vessels express molecular markers at low levels or can be entirely absent in resting quiescent blood vessels, and the ease of accessibility of these surface proteins by the blood stream makes them ideal targets [57]. Furthermore, malignant tumor cells are prone to mutations. In contrast, the tumor vasculature cells are genetically more stable and less susceptible to drug resistance [58]. Collectively, such favorable characteristics highlight the significance of the vascular 
targeting approach in cancer therapy. Numerous peptides homing specifically to tumor blood vessels have been identified (Table 1). Many of the specific molecular markers in tumor vessels (such as integrins) are associated with angiogenesis. Angiogenesis is the formation of new capillaries from pre-existing vessels for tumor nourishment and progression. Anti-angiogenic therapy acts by eliminating new vasculature and has proven to be a promising concept in tumor targeting based on the destruction of tumor microvasculature [59]. Peptide motifs RGD [60] and NGR[34], discovered through in vivo phage display, represent the first generation of vascular homing peptides, and these peptides will be discussed in detail.

RGD Motif. The peptide motif RGD (Fig. 2) was originally discovered in vitro in peptides that bind to different integrins overexpressed in tumor vasculature.[61, 62] Thereafter, the RGD peptide was shown to home in vivo to malignant melanoma and breast carcinoma xenografts in tumor-bearing mice [60]. The RGD peptides have high affinity for the integrins expressed in the angiogenic vasculature, in particular, $\alpha v \beta 3$ and $\alpha v \beta 5$ [62]. Along with integrin binding, RGD peptides are also capable of internalizing into the cells, interrupting the angiogenesis process that leads to cell death. Considerable numbers of synthetic RGD variants has been developed, including ACDCRGDCFCG (RGD-4C) and CRGDC (RGD-2C) which have different beneficial abilities in drug delivery [63]. Potent anti-angiogenic properties of RGD-4C have been shown using knockout mice experiments [64]. The use of tumor targeting peptides in general and RGD peptide in particular was validated with a cyclic pentapeptide RGD analogue, Arg-Gly-Asp-[65]Val or cyclo(RGDfV) known as Cilengitide® (Fig. 2, EMD 121974, Merck). Cilengitide possesses anti-angiogenic activity and is used in the treatment of glioblastoma. It is a selective $\alpha v \beta 3$ and $\alpha v \beta 5$ integrin antagonist. Despite promising phase I and II clinical trials, its use as an anticancer therapeutic has been discontinued due to failure in phase-III clinical trials [66]. 
Xiong et al. were the first to report the X-ray structure (PDB code 1L5G) of the extracellular segment of $\alpha \mathrm{v} \beta 3$ in complex with a cyclic pentapeptide RGD analogue, Arg-Gly-Asp- $\{\mathrm{N}-$ methyl-Val-\} (Fig. 3) [67]. The RGD sequence makes main contact with the integrin where the Arg and the Asp side chains point in opposite directions. The conformation of the RGD motif in the pentapeptide matches that of the RGD tripeptide in the natural ligand Echistatin. The arginine guanidinium group interacts with two Asp residues from integrin forming bidentate salt bridges, whereas the Asp (carboxylate oxygens) from RGD interacts with a $\mathrm{Mn}^{2+}$ ion and Tyr and Asn of integrin forming hydrogen bonds [67]. 
(A)

Linear RGD
(B)

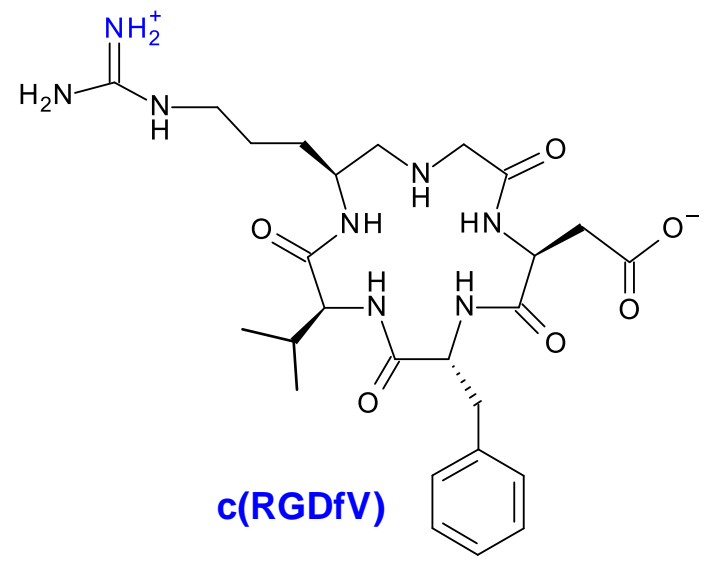

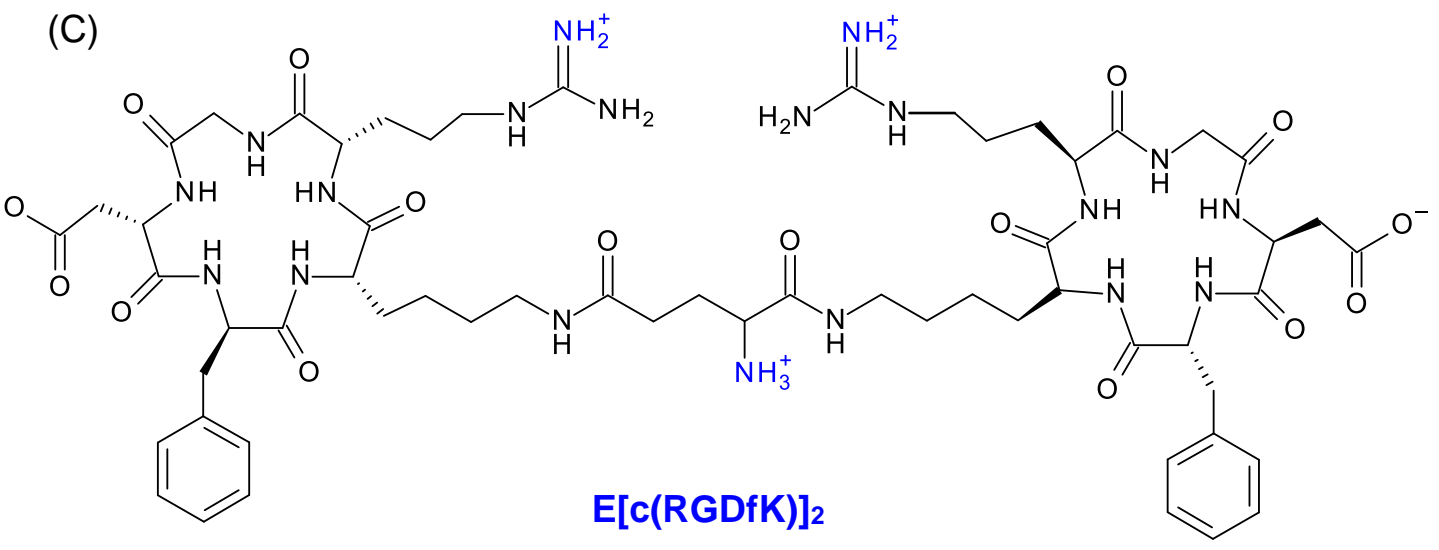

Fig. (2). Chemical structures of RGD peptides, (A) linear RGD, (B) cyclized RGD (Cilengitide or cyclo(-RGDfV-) peptide), and (C) RGD dimer. 


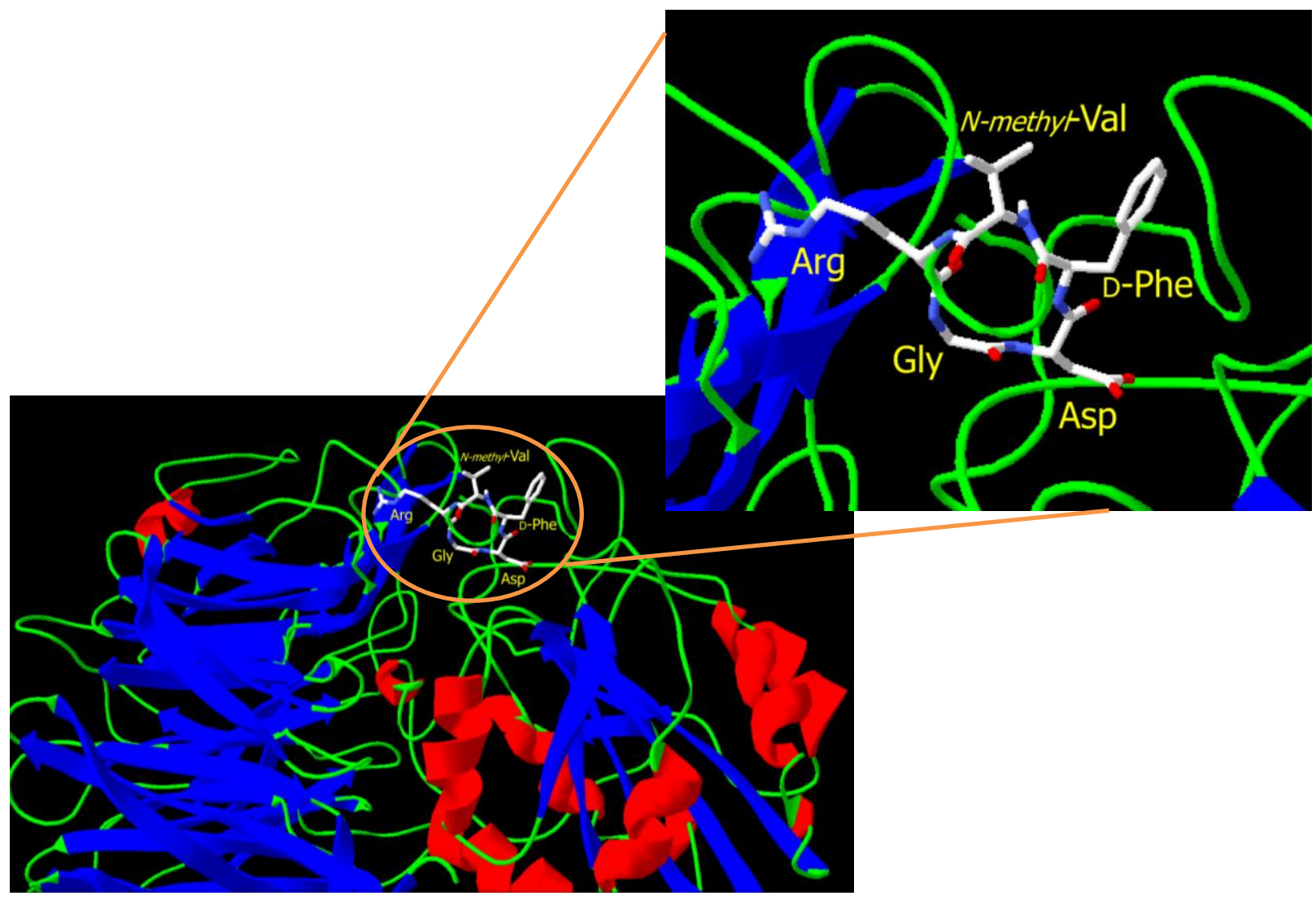

Fig. (3). Structure of cyclo(RGDf- $N[M e] \mathrm{V}$ ) in complex with $\alpha \mathrm{v} \beta 3$ (PDB ID: 1L5G) [67]. cyclo(RGDf-N[Me]V is shown as a stick model whereas portion of $\alpha v \beta 3$ is shown as ribbon drawing. The figure was created using SWISS PDB viewer.

Peptide Affinity Optimization. Structure-activity relationship (SAR) studies have been employed to the lead RGD sequence identified from phage display to identify structural features for enhancement of binding affinity and specificity of these molecules to $\alpha v \beta 3$ integrins. The flanking residues can affect the conformation of the RGD motif as well as control the peptide folding. In addition cyclization can confer rigidity to the peptide structure, greatly improving selectivity of the promiscuous RGD sequence for a specific integrin subtype. As shown in Fig. 2 , specificity and affinity for $\alpha v \beta 3$ integrin is enhanced in RGD peptide ligands by ring closure 
and flanking amino acids, which force the arginine and aspartic acid side residues into the proper conformation. SAR studies demonstrated that RGD peptide receptor binding affinity and selectivity can be enhanced by cyclization via linkers, such as thioether, disulfide, and rigid aromatic rings or other heterocycles [68, 69]. For instance, ACDCRGDCFCG (RGD-4C) with two disulfide bonds was at least 20 -fold more potent than similar RGD peptides with a single disulfide bond, and 200-fold more potent than commonly used linear RGD peptides [62]. A cyclic RGD pentapeptide framework is found to increase the binding affinity and selectivity regardless of which amino acid is placed at position 5, viz., c(RGDfK), c(RGDfE), and c(RGDfV). All three analogues show similar binding affinity to integrin [69]. As mentioned above, Cilengitide ${ }^{\circledR}$ targeting integrins $\alpha v \beta 3$ and $\alpha v \beta 5$ reached up to phase III trials for brain cancer glioblastoma. However it failed phase III clinical trials. When used in combination with standard temozolomide (TMZ) and radiotherapy (RT) in treatment of patients with newly diagnosed glioblastoma and with methylated $O^{6}$-methylguanine-DNA methyltransferase $(M G M T)$ gene promoter, the peptide failed to show any significant effect on patient survival compared to the control group [66].

To further improve peptide binding affinity, concepts like dimerization and multivalency have been utilized [70]. Recently, several laboratories have used bivalent or multivalent cyclic RGD moieties to attain high affinity $(\sim 10 \mathrm{nM})$ for $\alpha v \beta 3$. Since the natural mode of interactions between integrin $\alpha \mathrm{v} \beta 3$ and RGD-containing proteins such as vitronectin and fibronectin may involve multivalent binding sites, multivalent cyclic RGD peptides could provide more effective peptide ligands with enhanced targeting efficacy and cellular uptake [71]. For instance, cyclic RGD dimers such as $\mathrm{E}[\mathrm{c}(\mathrm{RGDfK})]_{2}$ and $\mathrm{E}[\mathrm{c}(\mathrm{RGDyK})]_{2}$ have been developed as targeting 
biomolecules for imaging purposes (Fig. 2C) [72]. The dimers yield enhanced binding rate as binding of one RGD motif significantly increases the local concentration of the second RGD motif.[72] Similarly, RGD peptide tetramers showed better integrin binding affinity than monomeric and dimeric analogues. Different linkers are used to conjugate monomeric peptides to one another, such as small flexible molecules (ethylene glycol units) or larger carriers (leucine zipper variant or the IgG Fc-region) [73]. Multivalency not only significantly improves the affinity but also facilitates internalization and may increase half-life combining the advantages of antibodies and small molecules $[74,75]$.

Improving Tumor Penetration. The success of targeted cancer therapy depends on the ability of the targeted drug molecules to reach primary and/or metastatic sites, and to penetrate deeply into the tumor.[76] Peptide sequence CRGDKGPDC, named internalizing RGD (iRGD), has been identified by screening cyclic CX7C peptide library against tumor vasculature of human prostate cancer.[75] Unlike the conventional RGD peptides discussed above, the iRGD motif has the ability to penetrate and become dispersed throughout the tumor tissue.[75, 77] This motif can also bind to other types of cancer including xenografts of pancreatic ductal and breast cancer. The mechanism underlying the iRGD tissue penetration occurs through a three-step process. First, the RGD motif binds to $\alpha v \beta$ integrins on the cell surface. A proteolytic cleavage then exposes a binding motif for neuropilin-1 (CRGDK fragment), and this mediates the penetration into tissue and cells. The binding motif follows a specific consensus $\mathrm{R} / \mathrm{KXXR} / \mathrm{K}$ (named $\mathrm{C}$-end rule),[76] that is known to bind neuropilin-1, a known mediator of vascular permeability induced by vascular endothelial growth factor (VEGF).[78] Accordingly, the CendR peptides increase vascular leakage and tissue penetration. The iRGD peptide enhanced the delivery of chemotherapeutics to solid tumors. In fact, the authors showed that conjugation of the peptide 
was not required. Co-administration of iRGD with the anticancer drug doxorubicin, nanoparticles carrying doxorubicin, or trastuzumab (a monoclonal antibody) improved the therapeutic index of the drug [79].

NGR Motif. The tripeptide motif NGR (Fig. 4), discovered by in vivo screening of phage libraries on human breast carcinoma xenografts, homes specifically to tumor blood vessels and other types of angiogenic blood vessels where it binds to aminopeptidase N (APN) receptor or CD13 receptor [34]. Several NGR-containing peptide sequences have been identified, such as disulfide bond cyclized CNGRC (cCNGRC) and cCVLNGRMEC, as well as linear analogues GNGRG and NGRAHA [16]. The peptide sequence cCNGRC has been coupled to different anticancer compounds such as doxorubicin [80], cisplatin [81], proapototic peptides [82], and tumor necrosis factor- $\alpha$ (TNF).[83] NGR conjugated to TNF (NGR-hTNF) is in phase II clinical trials $[84,85]$. An N- to C-terminal amide bond cyclized cKNGRE sequence is also reported for tumor targeting applications.[86] Pentapeptide analogues of NGR synthesized via on-resin click chemistry show specific binding to purified CD13 receptor as well as to cell lysates from CD13 ${ }^{+}$ SKOV-3 cancer cells.[87]

Structure-function studies with NGR sequences showed that the disulfide constraint enhances interaction with CD13 receptor, improving targeting ability ten-fold for cyclic CNGRC compared to linear GNGRG peptides.[88] Further, modification of cCNGRC with proline to produce cCPNGRC improved overall binding affinity to APN, and led to 30-fold lower IC50 for the inhibition of APN proteolytic activity.[89] Peptides containing the NGR motif can undergo spontaneous deamidation and generate Asp and isoAsp degradation products (Fig. 5).[90, 91] 
Flanking residues play an important role in NGR to isoaspartate-glycine-arginine (isoDGR) conversion with concomitant exchange of receptor affinity from CD13 to $\alpha v \beta 3$ integrin.[91]

Notably, the NGR sequence is also present in fibronectin (FN), an extracellular matrix protein involved in several key cellular processes.[90] Human FN is a large glycoprotein that contains three types of repeating modules, type I, II, and III. NGR with different flanking residues is present in each of the repeating modules of human FN. Soudy et al. used a peptide array-cell binding assay to identify NGR sequences displaying up to a 5-fold increase in binding to CD13 ${ }^{+}$ cells and very low binding to CD13 cell lines compared to the lead cyclic CVLNGRMEC peptide. A library of forty-five NGR containing peptides was synthesized in an array on cellulose membrane followed by on membrane (direct) screening against $\mathrm{CD}^{+} 3^{+}$and $\mathrm{CD} 13^{-}$cell lines. New peptide sequences such as YNGRT and CVLNGRSEC displayed high binding affinity for the $\mathrm{CD} 13^{+}$cells along with improved in vitro cellular uptake and specificity. Newly identified sequences bear a resemblance to NGR sequences present in human fibronectin [92].

(A)

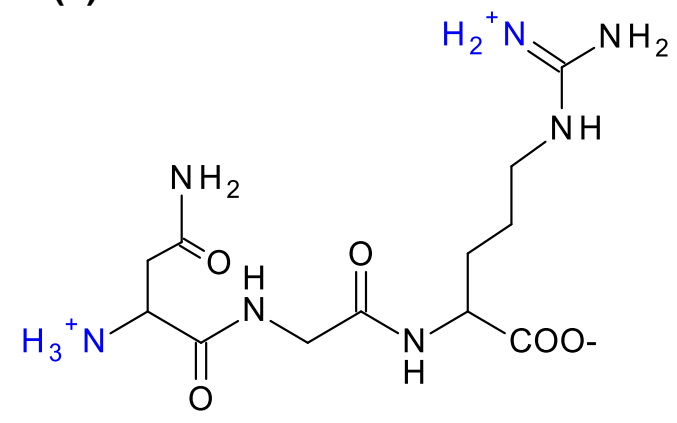

Linear NGR
(B)

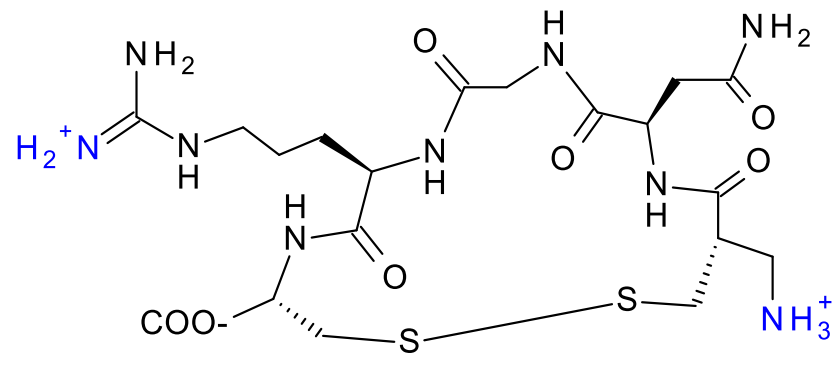

Cyclic CNGRC

Fig. (4). Chemical structures of linear NGR (A) and cyclic CNGRC (B). 

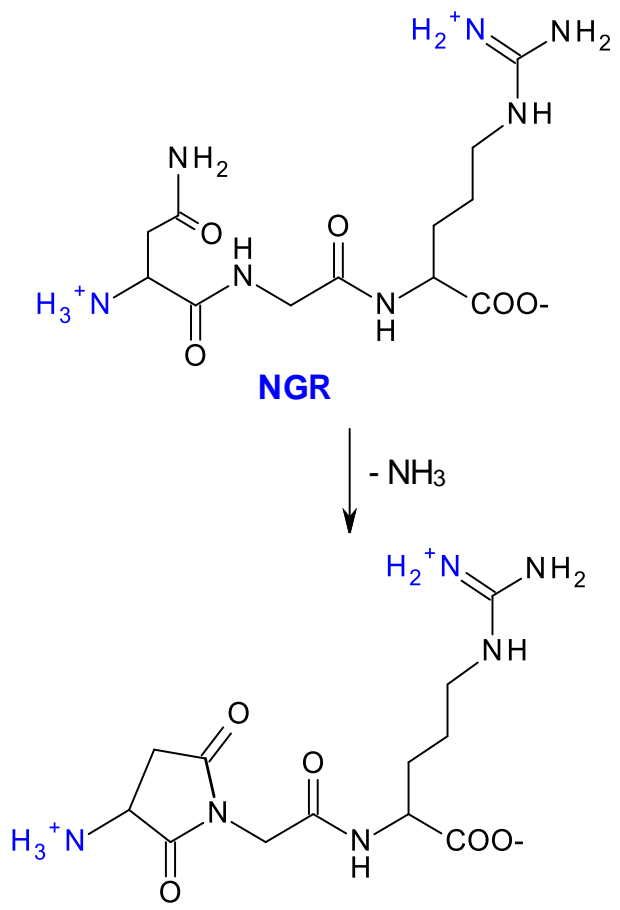

Succinimide Intermediate
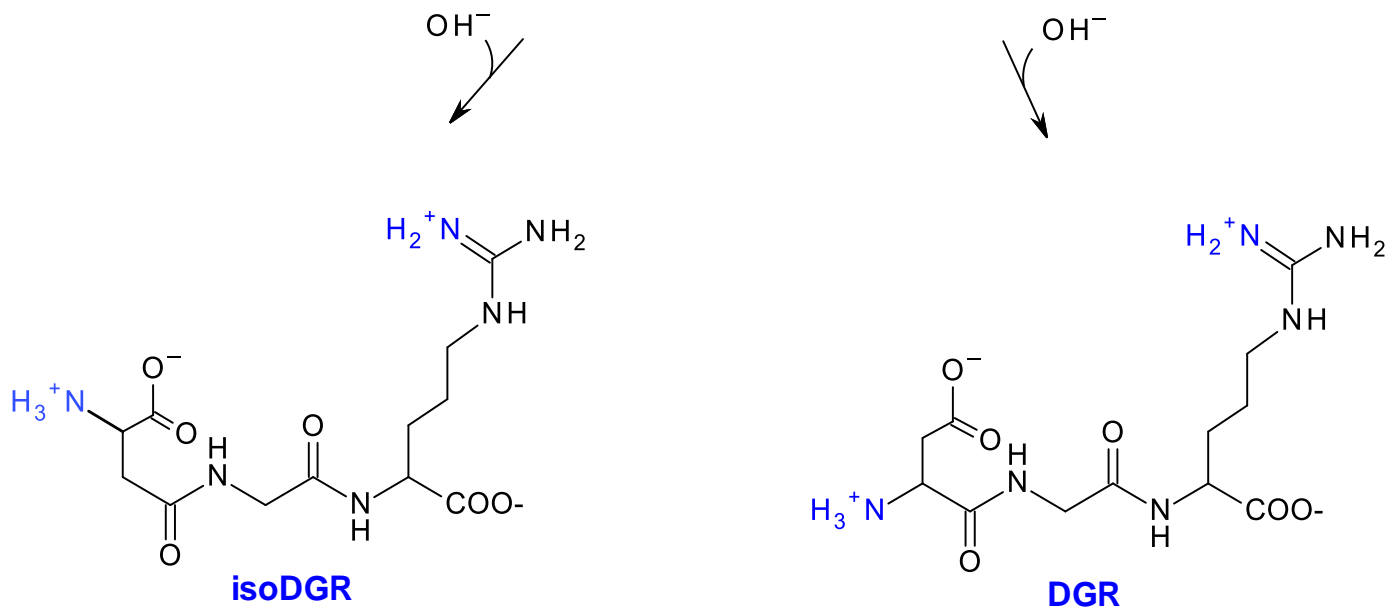

Fig. (5). NGR undergoes deamidation by nucleophilic attack of the backbone NH on the Asn side chain amide. Subsequently hydrolysis of the succinimide intermediate leads to the formation of isoDGR or DGR. 


\section{PEPTIDES HOMING TO TUMOR LYMPHATICS}

Peptides targeting tumor lymphatic vessels have also been identified using phage display (Table 1) $[93,94]$. The first peptide identified for lymphatic homing was LyP-1 (CGNKRTRGC) [95]. This peptide was identified using a combination of ex vivo/in vivo screens on MDA-MB-435 xenografts in nude mice. LyP-1 homed to the tumor-associated lymphatic vessels as well as to tumor cells in the hypoxic areas of tumors, but did not home to the tumor blood vessels. The LyP-1 receptor is a cell surface form of a mitochondrial protein $\mathrm{p} 32$ [96]. The protein $\mathrm{p} 32$ shows unusual cell surface expression in tumor lymphatics, tumor cells, and a subset of myeloid cells which adds to the specificity of LyP-1 homing to tumors [96]. Recently, a peptide named RMSII (CMGNKRSAKRPC) was identified to bind to rhabdomyosarcoma cell lines, and showed some sequence similarity to LyP-1 [97]. However, RMS-II homed better to RMS xenografts in vivo than LyP-1. Furthermore, RMS-II recognized tumor blood vessels, and not tumor lymphatic vessels indicating different specificities of the two peptides [97] .

Another study showed that lymphatics homing peptides LyP-1 and LyP-2 (CNRRTKAGC) with homologous sequences, home to lymphatics of different tumor types [98]. LyP-1 recognizes the lymphatics and tumor cells in MDA-MD-435 breast carcinoma, MMTV-PyMT breast carcinoma, and KRIB osteosarcoma xenografts as well as their metastatic lesions but not in the C8161 melanomas, while the LyP-2 peptide homes to the lymphatics of the C8161 melanomas and K14-HPV16 skin and cervical carcinomas but not to the MDA-MB-435 tumors [98]. The specificity of these peptides was further demonstrated by conjugation of the two peptides with different fluorophores followed by simultaneous injection into the same animals. LyP-1 homed only to the lymphatics of MDA-MB-435 tumors and LyP-2 to the lymphatics of K14-HPV16 cervical carcinomas [98]. These studies indicate that tumor lymphatics are similar to tumor 
blood vessels, expressing tumor type-specific markers that are distinct from the blood vessel markers of the same tumor.

\section{CANCER TARGETING PEPTIDES IN DRUG DELIVERY}

Cancer targeting peptides have been extensively studied for tumor-specific drug delivery. Here we reviewed key recent examples based on the different strategies for targeting three receptors (integrin, aminopeptidase $\mathrm{N}$, epidermal growth factor), and discussed the prospects of such constructs to specifically target tumor cells. Peptide targeted drug delivery is achieved mainly by either conjugating cancer specific peptides to chemotherapeutic drugs or using these peptides to modify the surface of different drug carriers (nanoparticle, micelles, dendrimers, and liposomes) that encapsulate anticancer drugs and deliver them preferentially to targeted tumor sites [99, 100]. Peptide-drug conjugates have high specificity and can penetrate the tumor better than a large nanocarrier, whereas drug carriers such as liposomes and polymers can carry more drug molecules per targeting event and have longer circulation times in blood. In general, tumor-specific delivery of chemotherapeutics by either method increases the therapeutic efficacy of anticancer drugs and limits toxicity to normal tissues. Higher concentrations of drug specifically reaching the tumor will decrease the phenomena of incomplete tumor response or the emergence of tumor drug resistance. Overall, this will maintain the quality of the cancer patient's life while efficiently attacking the cancer.

\section{PEPTIDE-DRUG CONJUGATES}

Peptide-drug conjugates (PDCs) are being developed for the targeted delivery of drugs to the cancer site. A wide variety of drugs such as antisense oligonucleotides, toxins, chemotherapeutic agents and proapoptotic peptides have been conjugated to cancer targeting peptides for site- 
specific delivery [101]. Remarkable success in targeting the antitumor agent cytokine TNF into tumors has been reported with RGD and NGR peptides. The targeted cytokine was effective in 1,000-fold lower dose than the usual dose, and effectively decreased the side effects associated with the high toxicity of the cytokine [102]. A randomized double-blind phase III study of NGR-TNF (in combination with chemotherapy or supportive care) started in 2010 in patients with malignant pleural mesothelioma [103]. Doxorubicin (Dox) has been conjugated to Luteinizing-hormone-releasing hormone LHRH agonist and antagonist peptides for selectively targeting cancer cells. The ability of LHRH-Dox conjugate to inhibit cancer cell growth (i.e., breast, prostate, mammary, and ovarian cancer cells) was comparable to that of the corresponding individual drugs[102]. In vivo studies indicated that the drug-agonist conjugates are less toxic and more potent than the corresponding drug (Dox). In another study, a DoxRGD4C conjugate was synthesized for drug targeting to the vasculature of breast tumor model which expresses $\alpha v \beta 3$ in the angiogenic blood vessels and the tumor cells. The conjugate proved to be equally effective to free Dox in vitro and, more importantly, demonstrated improved inhibition of tumor growth and spreading of metastases in mice [34]. In addition to an improved efficacy, Dox-RGD4C conjugate also displayed reduced toxicity to liver and heart. Soudy et al. showed that conjugating Dox to peptide 18-4 breast cancer-specific peptide through ester linkage was 6-10 times more selective for breast cancerous cells (MCF-7 and MDA-MB-435) over noncancerous cells (HUVECs and MCF-10A). In addition, ester conjugate displayed similar toxicity to free Dox toward the breast cancerous cells and 40 times less toxicity toward the noncancerous cells. The conjugate was 4-fold more toxic toward the Dox resistant MDA-MB435-MDR cells than the free Dox [104]. 
Similarly, antibody-drug conjugates (ADCs) can be very effective. An ADC, Ado-trastuzumab emtansine (antibody-drug conjugate pairing a HER2 blocker with a tubulin inhibitor, Genentech) for HER2-positive metastatic breast cancer was approved recently and is in clinical use for cancer treatment [105]. PDCs offer solutions for several problems encountered with ADCs, as PDCs allow control over peptide-drug ratio and the chemistry of conjugation is much easier. Owing to the small size of peptide, it can better escape from the vasculature and diffuse through the interstitial space of tumors. There is also a low chance of eliciting an immune response when compared to antibodies. Another advantage is that some PDCs were found to escape pglycoprotein efflux that causes drug resistance. On the contrary, the activity of many ADCs was poor in cells that express these efflux pumps [106, 107]. One study attributed the poor efficacy of ADCs to their degree of hydrophobicity, as most of the reported p-glycoprotein efflux pump substrates are hydrophobic. They hypothesized that an antibody conjugated to drugs via a hydrophilic linker would be a poor substrate of the efflux pump, thus circumventing drug resistance in ADCs [108]. PDCs have also reached clinical trials. A peptide-drug conjugate, GRN1005 (phase II trials), composed of three molecules of paclitaxel covalently linked to 19mer angiopep-2 peptide (TFFYGGSRGKRNNFKTEEY) targets the low-density lipoprotein receptor-related protein 1(LRP-1). LRP-1 is a highly expressed receptor on the surface of the blood brain barrier. GRN1005, a prodrug, showed therapeutic efficacy in patients with advanced solid brain tumors, brain metastases and patients who failed prior taxane treatment. Such advances emphasize the positive prospects of PDCs in cancer treatment [103].

\section{PEPTIDE MODIFIED NANOCARRIER}

Cancer targeting peptides surface conjugated to nanocarriers offers several advantages compared to the direct conjugation methods highlighted above. Nanocarriers hold multiple ligands on each 
particle allowing multivalent interactions between the ligands and the receptors, which results in more proficient targeting. Beside, carriers simply preserve the drug from degradation in physiological conditions and prevent its direct contact with normal tissues thereby minimizing undesirable off-target effect. Nanocarriers are larger in size $(10-500 \mathrm{~nm})$ compared to traditional drugs that are easily filtered off by the renal excretion route (cut off size for renal excretion is 5 $\mathrm{nm})$. This extends the drug half-life and enables its extended release, improving efficacy. Different sorts of nanocarriers functionalized with peptide tumor targeting ligands have been investigated and some representative recent studies are listed in Table $\mathbf{2}$.

The use of peptide-modified drug loaded nanocarriers such as liposomes, micelles, and polymers for tumor-targeted delivery has been extensively studied [109, 110]. Reported studies showed that peptide-targeted nanocarriers containing anti-cancer agents are more effective in reducing tumor growth and in enhancing survival in mice when compared to non-targeted ones. Peptide RGD is the first tumor-targeting peptide that has been used to modify nanocarriers to improve the therapeutic efficacy of the loaded chemotherapeutic drug. RGD4C-decorated polymeric micelles effectively improved the therapeutic efficacy of Dox conjugated to the core forming block either through acid cleavable hydrozone or stable amide linkages in SCID mice bearing wild or resistant MDA-MB-435 tumor, respectively [111]. In another study, NGR liposomal doxorubicin was administered to mice in three cycles of $3 \mathrm{mg} / \mathrm{kg} /$ week dosing. The targeted liposomal formulation showed rapid tumor regression and metastasis inhibition while mice treated with mismatched peptide targeted liposomal Dox formed large neovasculature [112]. We found that peptide p160 conjugation of the polymeric micelles enhanced the selective cytotoxicity of encapsulated paclitaxel (PTX) against MDA-MB-435 cancer cells over normal HUVEC and MCF-10A cells [113]. Further, a liposomal formulation of Dox surface-coated 
with a p160 analogue (peptide 18-4) showed better cytotoxicity against MDA-MB-435 compared to non-targeted liposomes [114]. NOD-SCID mice bearing MDA-MB-435 xenografts treated with peptide 18-4 conjugated liposomal Dox displayed a 5-fold reduction in the mean relative tumor volume compared to mice treated with non-targeted Dox liposomes [115]. These examples highlight the potential of peptide-nanocarrier conjugates as drug carriers, which are being increasingly pursued by drug delivery researchers for targeted therapy of cancer.

\section{CANCER TARGETING PEPTIDES IN DIAGNOSTICS}

There is great interest in the use of cancer targeting peptides for in vivo diagnostic applications due to their high tumor selectivity [116]. Peptides are considered as ideal receptor-guided vectors in tumor imaging. This is derived from their favorable pharmacokinetic characteristics. Peptides can tolerate harsh conditions such as $\mathrm{pH}$, temperature, etc. during chemical modifications and diverse radiolabeling techniques. Because of their compact size, peptides have tumor uptake with concomitant rapid clearance from blood and non-target tissues. Peptides have been attached to a variety of dyes and fluorescently labelled nanoparticles, such as quantum dots, for in vivo optical fluorescence imaging [117]. Different peptide sequences have shown promising results in tumor imaging. The best example is somatostatin analogs that target somatostatin receptor overexpressed in neuroendocrine tumors. ${ }^{111}$ In-DTPA-octreotide $\left({ }^{111} \mathrm{In}\right.$ Octreosan) is the first US Food and Drug administration approved diagnostic radiopeptide for the imaging of patients with neuroendocrine tumors [118]. Other naturally occurring peptides sequences (such as bombesin/gastrin releasing peptides) have shown great promise in the visualization of BN/GPR overexpressing tumors including prostate, breast, and lung cancer [119]. A number of other specific peptides, such as vasoactive intestinal peptide, neurotensin, 
and cholecystokinin/gastrin are currently under preclinical or clinical investigation to determine their true potential in the diagnosis or treatment of human cancer [120].

The RGD peptide has been used for targeted delivery of various imaging agents. RGDconjugated radiolabeled iron oxide nanoparticles were used to image subcutaneous human glioma xenograft tumors using a positron emission tomography/magnetic resonance imaging (PET/MRI) dual imaging system [121]. Moreover, the RGD-targeted MRI-detectable fluorescent liposomes and the RAD-conjugated liposomes (as a control for specificity) accumulated in the tumor by different mechanisms. The RGD-liposomes specifically associated with blood vessels that expressed $\alpha v \beta 3$ at the angiogenic endothelium, whereas the RADliposomes were located in the extravascular compartment, indicating extravasation of the liposomes [122]. Radioactive RGD peptides are considered a potential class of radiotracers for tumor diagnosis and monitoring therapeutic outcomes in cancer patients [123]. Tracers like $\left[{ }^{18} \mathrm{~F}\right]$-galacto-c(RGDfK) as well as $\left[{ }^{18} \mathrm{~F}\right]$-bearing tracers with RGD4C and PEG linker, are being investigated for noninvasive imaging of integrin expression in cancer patients. In addition, cyclic NGR peptide (cNGR) was successfully used for targeted imaging of angiogenic vessels in the ischemic heart [124]. Additional recent studies representing the use of peptide-tumor ligands in cancer imaging and diagnosis are listed in Table 3. Overall, these studies show the potential use of peptide-targeted delivery of imaging agents for tumor imaging and visualization.

\section{CONCLUSIONS AND OUTLOOK}

Various in vitro and in vivo preclinical studies have shown that tumor-targeting peptides are powerful candidates for ligand targeted delivery of drugs, drug nanocarriers and diagnostics 
specifically to tumors. Although a growing number of tumor-targeting peptides are being identified by different screening tools, the number successfully reaching clinics is not meeting expectations. Peptides as drug delivery vehicles suffer from numerous obstacles and have several important parameters that need to be optimized for the successful translation of these targeting constructs to clinical applications. For instance, peptides have a short half-life in biological fluids, caused mainly by proteolytic cleavage and renal clearance. Increasing the peptide stability against proteolytic digestion can be achieved by incorporating nonproteinogenic amino acids into the peptide sequence, or via peptide cyclization. On the other hand, increasing the molecular weight of the peptide above the renal clearance limit by coupling to a carrier molecule such as albumin would decrease its renal clearance. Peptides, due to their small size, suffer from low binding affinity to their putative receptor on tumor cells. Building multimeric targeting structures by grafting several peptides onto a multi-headed core may compensate for the low binding affinity to achieve effective targeting.

Peptide ligand binding to the tumor expressed receptor is a crucial step in initiating signals, and the study of ligand-receptor interaction can reveal the molecular basis for both binding and receptor activation. Synthetic peptide libraries are useful tools for carrying out such structureactivity studies. Peptide leads identified using phage display can be further optimized by the use of synthetic peptide libraries which leads to smaller derivatives with increased tumor penetration and target affinity. In addition, structure-function studies are important for identifying the role of each amino acid in receptor recognition and targeting. For the successful application of peptides in the development of nanosystem constructs, special consideration should be made during the synthesis. For instance, optimal peptide density for cell-targeting capability and internalization should be obtained, and the distance of the peptide from the nanostructure surface should be 
adjusted using a linker in order to maintain the conformation of the peptide required for high affinity binding to the target. Peptide density of nanoparticle surface can affect the subsequent ligand/receptor binding interactions, as well as particle stability, drug loading and release characteristics. Optimization of these characteristics could further improve the therapeutic potential of cancer targeting peptides in drug delivery systems. It is certain that with several-fold improvement in the therapeutic efficacy of cancer drugs and development of efficient cancer imaging probes using cancer targeting peptides, we are bound to see more peptide-based systems entering into clinical trials during the coming years.

\section{ACKNOWLEDGEMENT}

This work was supported by the Natural Sciences and Engineering Research Council of Canada (NSERC) and Canadian Institutes for Health Research (CIHR). 
Table 2. A few representative nanocarriers functionalized with tumor targeting peptide ligands

\begin{tabular}{|c|c|c|c|c|}
\hline Carrier System & $\begin{array}{l}\text { Targeting } \\
\text { Peptide }\end{array}$ & Drug & In vivo System & In Vivo Results [reference] \\
\hline \multicolumn{5}{|l|}{ Integrins } \\
\hline Methoxy PEG-PLGA-PLL Nanoparticles & cRGD & $\begin{array}{l}\text { Mitoxantrone } \\
\text { (DHAQ) }\end{array}$ & $\begin{array}{l}\text { MDA-MB-231 } \\
\text { breast cancer- } \\
\text { bearing mice }\end{array}$ & $\begin{array}{l}\text { Specific uptake in tumor ( } 2.4 \text {-fold } \\
\text { increase), } 4 \text {-fold decrease in tumor } \\
\text { volume and higher tumor growth } \\
\text { inhibition compared to free drug, and } \\
\text { low inherent in vivo physiological } \\
\text { toxicity.[125] }\end{array}$ \\
\hline Methoxy PEG-PLGA-PLL Nanoparticles & cRGD & Bufalin & $\begin{array}{l}\text { SW620 colon } \\
\text { cancer-bearing mice }\end{array}$ & $\begin{array}{l}\text { Better tumor targeting and longer residue } \\
\text { time in vivo, 2-fold decrease in tumor } \\
\text { volume, and higher tumor growth } \\
\text { inhibition compared to free drug.[126] }\end{array}$ \\
\hline $\begin{array}{l}\text { Methoxy PEG-b-P(Glu) polymeric } \\
\text { micelles and } \\
\text { Maleimide-PEG-b-P(Glu) polymeric } \\
\text { micelles }\end{array}$ & cRGD & $\begin{array}{l}\text { (1,2-Diamino } \\
\text { cyclohexane) } \\
\text { platinum(II) } \\
\text { or (DACHPt) }\end{array}$ & $\begin{array}{l}\text { U87MG } \\
\text { glioblastoma tumor- } \\
\text { bearing mice }\end{array}$ & $\begin{array}{l}\text { Higher tumor accumulation, higher } \\
\text { permeability from vessels into the tumor } \\
\text { parenchyma compared to the control } \\
\text { PM, 10-fold decrease in tumor volume, } \\
\text { compared to saline treated group.[127] }\end{array}$ \\
\hline $\begin{array}{l}\text { HSPC/CHOL/MBPE/DSPE-PEG2000 } \\
(54.5: 38.0: 2.5: 5.0 \text { molar ratio) }\end{array}$ & cRGD & Doxorubicin & $\begin{array}{l}\text { Male Sprague- } \\
\text { Dawley rats }\end{array}$ & $\begin{array}{l}\text { Higher cell uptake by U87MG cells } \\
\text { compared with non-targeted, improved } \\
\text { pharmacokinetics in rats, longer } \\
\text { systemic circulation time (8.3-fold } \\
\text { increase in area under the curve) } \\
\text { compared with free Dox. [128] }\end{array}$ \\
\hline
\end{tabular}




\section{Aminopeptidase $N$}

\begin{tabular}{|c|c|c|c|}
\hline Sterically stabilized liposome (SSL) & Paclitaxel & $\begin{array}{l}\text { HT1080 tumor- } \\
\text { bearing mice }\end{array}$ & $\begin{array}{l}\text { Better in vivo pharmacokinetic profile, } \\
\text { (10-fold increase in half-life, } 2.5 \text { fold } \\
\text { increase in bioavailability compared to } \\
\text { Taxol treated group). The average } \\
\text { tumor weight was } 11 \text { times less than } \\
\text { saline treated group. In addition, no } \\
\text { significant weight loss was } \\
\text { observed.[129] }\end{array}$ \\
\hline DSPE-PEG micelles & Paclitaxel & $\begin{array}{l}\text { C6 glioma tumor- } \\
\text { bearing mice }\end{array}$ & $\begin{array}{l}\text { Tumor weight inhibition (\% decreased } \\
\text { by } 7 \text {-fold compared to Taxol treated } \\
\text { group). Higher anti-angiogenic activity } \\
\text { compared to saline treated group.[130] }\end{array}$ \\
\hline
\end{tabular}


Table 3. A few representative tumor targeting peptide ligands in cancer imaging

\begin{tabular}{|c|c|c|c|}
\hline $\begin{array}{l}\text { Imaging Probe } \\
\text { (Application) }\end{array}$ & $\begin{array}{l}\text { Targeting } \\
\text { Peptide }\end{array}$ & In vivo System & In Vivo Results [reference] \\
\hline \multicolumn{4}{|l|}{ Integrins } \\
\hline $\begin{array}{l}{ }^{68} \mathrm{Ga}-\mathrm{TRAP}(\mathrm{RGD})_{3} \\
(\mathrm{PET} \text { imaging) }\end{array}$ & $\begin{array}{l}\text { c(RGDfK) } \\
\text { peptide } \\
\text { trimer }\end{array}$ & $\begin{array}{l}\text { CD-1 athymic nude } \\
\text { mice bearing } \\
\text { M21/M21L human } \\
\text { melanoma } \\
\text { xenografts }\end{array}$ & $\begin{array}{l}\left.{ }^{68} \text { Ga-TRAP(RGD }\right)_{3} \text { exhibits } 7.3 \text { and } 7.6 \text { fold higher affinity to } \alpha_{v} \beta_{3} \\
\text { integrins compared to }{ }^{18} \text { F-Galacto-RGD and }{ }^{68} \text { Ga-NODAGA- } \\
\text { RGD in M21 cells. Excellent pharmacokinetics in mice, fast renal } \\
\text { clearance, and high in vivo stability. Higher tumor specific uptake } \\
\text { (6 fold) than that of the other tracers. [131] }\end{array}$ \\
\hline $\begin{array}{l}\text { G5.NHAc- } \mathrm{RGD}-\mathrm{Fe}_{3} \mathrm{O}_{4} \\
\mathrm{NPs} \\
\text { (Magnetic resonance } \\
\text { imaging) }\end{array}$ & $\begin{array}{l}\text { G5.NH2- } \\
\text { RGD } \\
\text { poly(amido } \\
\text { amine) } \\
\text { dendrimers }\end{array}$ & $\begin{array}{l}\text { C6 glioma tumor- } \\
\text { bearing nude mice }\end{array}$ & $\begin{array}{l}\text { Targeted NPs show good water and colloidal stability, a relaxivity } \\
\text { (r2) of } 5.899 \mathrm{mM}^{-1} \mathrm{~s}^{-1} \text {, and good hemocompatibility and } \\
\text { biocompatibility over the studied concentration range. Cellular } \\
\text { uptake studies, in vitro and in vivo MR imaging showed that the } \\
\text { developed G5.NHAc-RGD-Fe } \mathrm{O}_{4} \mathrm{NPs} \text { have a high affinity for C6 } \\
\text { glioma cells in mice that overexpress } \alpha \mathrm{v} \beta 3 \text { receptors compared to } \\
\text { non-targeted nanoparticles.[132] }\end{array}$ \\
\hline $\begin{array}{l}{ }^{68} \mathrm{Ga}-\mathrm{NOPO}-\mathrm{cRGD} \\
\text { (PET imaging) }\end{array}$ & $\begin{array}{l}\text { cyclo(RGD } \\
\mathrm{fK})\end{array}$ & $\begin{array}{l}\text { M21/M21L } \\
\text { xenografted athymic } \\
\text { CD-1 nude mice }\end{array}$ & $\begin{array}{l}\text { Rapid and specific uptake in M21 tumor xenografts, and was } \\
\text { found stable in vivo. Very rapid pharmacokinetics and renal } \\
\text { clearance were observed, enabling high-contrast PET imaging } \\
\text { shortly after tracer administration, which renders it an interesting } \\
\text { tracer for PET imaging of integrin status in an outpatient clinical } \\
\text { setting.[133] }\end{array}$ \\
\hline $\begin{array}{l}{ }^{64} \mathrm{Cu} \text {-integrated } \mathrm{Au} \mathrm{NMs} \\
\mathrm{RGD}\left(\left[{ }^{64} \mathrm{Cu}\right] \mathrm{Au} \mathrm{NMs}\right)\end{array}$ & cRGD & $\begin{array}{l}\text { U87MG } \\
\text { glioblastoma }\end{array}$ & $\begin{array}{l}\text { Two fold increase in tumor uptake compared to non-targeted } \\
\text { nanrods. The cell uptake of RGD-Au NRs was nearly } 2.8 \text { and } 3.0\end{array}$ \\
\hline
\end{tabular}




\begin{tabular}{|c|c|c|c|}
\hline (PET imaging) & & xenograft model & $\begin{array}{l}\text { times that of Au NRs and RGD-Au NPs p blocking (RGD-Au NRs } \\
\text { plus free RGD to block the target), respectively.[134] }\end{array}$ \\
\hline $\begin{array}{l}\left.\left[{ }^{18} \mathrm{~F}\right] 6 \mathrm{Glc}-\mathrm{RGD}\right),\left[{ }^{18} \mathrm{~F}\right] \mathrm{Gal}- \\
\mathrm{RGD},\left[{ }^{18} \mathrm{~F}\right] \mathrm{Mlt}-\mathrm{RGD} \\
\left.\left[{ }^{18} \mathrm{~F}\right] \mathrm{Cel}-\mathrm{RGD}\right) \\
\text { (PET imaging) }\end{array}$ & $\begin{array}{l}\text { c(RGDfPra } \\
\text { ) }\end{array}$ & $\begin{array}{l}\text { U87MG tumor- } \\
\text { bearing nude mice }\end{array}$ & $\begin{array}{l}{\left[{ }^{18} \mathrm{~F}\right] 6 \mathrm{Glc}-\mathrm{RGD} \text { and }\left[{ }^{18} \mathrm{~F}\right] \mathrm{Mlt}-\mathrm{RGD} \text { showed significantly decreased }} \\
\text { liver and kidney uptake by PET relative to the } 2 \text { - } \\
{\left[{ }^{18} \mathrm{~F}\right] \text { fluoroglucosyl analog }[18 \mathrm{~F}] 2 \mathrm{Glc}-\mathrm{RGD} \text {, and showed specific }} \\
\text { tumor uptake in vivo. }\left[{ }^{18} \mathrm{~F}\right] \mathrm{Mlt}-\mathrm{RGD} \text { revealed higher uptake and } \\
\text { retention in the U87MG tumor comparable to that of }\left[{ }^{18} \mathrm{~F}\right] \text { Galacto- } \\
\text { RGD. The uptake for }[18 \mathrm{~F}] \text { Galacto-RGD in the M21 tumor model } \\
\text { is twice as high as that of [18F]Mlt-RGD in U87MG tumors. } \\
\text { Difference could be most likely ascribed to differences in the } \\
\text { overall } \alpha \mathrm{v} \beta 3 \text { or } \alpha \mathrm{v} \beta 5 \text { integrin expression between the M21 and } \\
\text { U87MG tumors. While }\left[{ }^{18} \mathrm{~F}\right] 6 \mathrm{Glc}-\mathrm{RGD} \text { has favorable tumor-to- } \\
\text { blood ratios in the U87MG tumor model, but only low tumor } \\
\text { retention, }\left[{ }^{18} \mathrm{~F}\right] \mathrm{MltRGD} \text { proved to have slower blood clearance but } \\
\text { even less uptake in the kidney and liver.[135] }\end{array}$ \\
\hline \multicolumn{4}{|l|}{ Aminopeptidase $N$} \\
\hline $\begin{array}{l}{ }^{64} \mathrm{Cu}-\mathrm{DOTA}-\mathrm{NGR} 1 \text { and } \\
{ }^{64} \mathrm{Cu}-\mathrm{DOTA}-\mathrm{NGR} 2 \\
\text { (microPET imaging) }\end{array}$ & $\begin{array}{l}\text { GGGCNG } \\
\text { RC }\end{array}$ & $\begin{array}{l}\text { Female athymic } \\
\text { nude mice CD13- } \\
\text { positive HT-1080 } \\
\text { fibrosarcoma } \\
\text { xenografts }\end{array}$ & $\begin{array}{l}{ }^{64} \mathrm{Cu}-\mathrm{DOTA}-\mathrm{NGR}{ }_{1} \text { and }{ }^{64} \mathrm{Cu}-\mathrm{DOTA}-\mathrm{NGR}_{2} \text { showed significant } \\
\text { reduction of tumor uptake with a co-injected blocking dose of } \\
\text { cyclic NGR. }{ }^{64} \mathrm{Cu}-\mathrm{DOTA}-\mathrm{NGR}_{2} \text { displayed higher tumor uptake } \\
\text { and slower tumor washout in } \mathrm{CD} 13 \text {-positive } \mathrm{HT}-1080 \text { tumor } \\
\text { xenografts as compared to } 64 \mathrm{Cu}-\mathrm{DOTA}-\mathrm{NGR}_{1} \cdot[136]\end{array}$ \\
\hline $\begin{array}{l}{ }^{68} \text { Ga-NOTA-c(NGR) } \\
\text { (PET imaging) }\end{array}$ & $\begin{array}{l}\mathrm{c}[\mathrm{KNGRE}] \\
-\mathrm{NH}_{2}\end{array}$ & $\begin{array}{l}\text { Orthotopic and } \\
\text { heterotopic } \\
\text { transplanted } \\
\text { mesoblastic } \\
\text { nephroma }(\mathrm{NeDe}) \\
\text { bearing Fischer-344 } \\
\text { rats }\end{array}$ & $\begin{array}{l}{ }^{68} \text { Ga-NOTA-c(NGR) uptake was significantly lower in abdominal } \\
\text { organs in comparison with }{ }^{68} \mathrm{Ga}-\mathrm{NODAGA}-[\mathrm{c}(\mathrm{RGD})]_{2} \text {. In NeDe } \\
\text { tumor bearing rats }{ }^{68} \mathrm{Ga}-\mathrm{NOTA}-\mathrm{c}(\mathrm{NGR}) \text { showed higher } \\
\text { accumulation in the tumors than that of the }{ }^{68} \mathrm{Ga}-\mathrm{NODAGA}- \\
\text { [c(RGD)]2. Using orthotopic transplantation, metastases were } \\
\text { developed which showed specific }{ }^{68} \mathrm{Ga}-\mathrm{NOTA}-\mathrm{c}(\mathrm{NGR}) \\
\text { uptake.[137] }\end{array}$ \\
\hline
\end{tabular}


TRAP= (1,4,7-triazacyclononane-1,4,7-tris[(2-carboxyethyl)methylenephosphinic acid]), Glc= glucosyl, Gal=galactosyl , Mlt= maltosyl, Cel $=$ cellobiosyl. NOPO= (1,4,7-triazacyclononane-1,4- bis[methylene(hydroxymethyl)phosphinic acid]-7-[methylene(2-carboxyethyl)phosphinic acid]. Fe3O4 NPs= Iron oxide NPs. PET= positron emission tomography. DOTA= 1,4,7,10-

tetraazacyclododecane-1,4,7,10-tetraacetic acid. NOTA= 1,4,7-triazacyclononane-triacetic acid

\section{ABBREVIATIONS}

ADCs $=$ antibody-drug conjugates

APN =aminopeptidase $\mathrm{N}$

Dox $=$ Doxorubicin

EGFR= Epidermal growth factor receptor

ELP = elastin like polypeptide

$\mathrm{FGF}=$ fibroblast growth factor

$\mathrm{FN}=$ fibronectin

hEGFR $=$ human epidermal growth factor receptor

IL-4R= interleukin 4 receptor

iRGD = internalizing RGD

$\mathrm{LD}=$ liposomal doxorubicin

$L H R H=$ luteinizing-hormone-releasing hormone

LRP-1 = low-density lipoprotein receptor-related protein 1

$M G M T=$ methylated $O^{6}$-methylguanine-DNA methyltransferase

OBOC $=$ one-bead one compound

$\mathrm{PDCs}=$ peptide-drug conjugates

$\mathrm{PEG}=$ poly(ethyleneglycol)

PTX= paclitaxel

RGD = Arg-Gly-Asp

$\mathrm{RT}=$ radiotherapy

$\mathrm{SAR}=$ structure-activity relationship 
$\mathrm{TMZ}=$ temozolomide

TNF- $\alpha=$ tumor necrosis factor

TGF- $\alpha=$ transforming growth factor

$\mathrm{TK}=$ tyrosine kinase

VEGF $=$ vascular endothelial growth factor 
[1] Cho, K.; Wang, X.; Nie, S.; Chen, Z.; Shin, D.M., Therapeutic Nanoparticles for Drug Delivery in Cancer. Clinical Cancer Research, 2008, 14 (5), 1310-1316.

[2] Liang, X.-J.; Chen, C.; Zhao, Y.; Wang, P.C., 2009; Vol. 596, pp 467-488.

[3] Aird, W.C., Phenotypic Heterogeneity of the Endothelium. Circulation research, 2007, 100 (2), $174-190$.

[4] Wang, B.e.a., eds Drug Delivery: Principles and Applications, . Weily, 2005.

[5] Ladner, R.C.; Sato, A.K.; Gorzelany, J.; de Souza, M., Phage display-derived peptides as therapeutic alternatives to antibodies. Drug discovery today, 2004, 9 (12), 525-529.

[6] Allen, T.M., Ligand-targeted therapeutics in anticancer therapy. Nat Rev Cancer, 2002, 2 (10), $750-763$.

[7] Desgrosellier, J.S.; Cheresh, D.A., Integrins in cancer: biological implications and therapeutic opportunities. Nat Rev Cancer, 2010, 10 (1), 9-22.

[8] Dunehoo, A.L.; Anderson, M.; Majumdar, S.; Kobayashi, N.; Berkland, C.; Siahaan, T.J., Cell adhesion molecules for targeted drug delivery. Journal of Pharmaceutical Sciences, 2006, 95 (9), 1856-1872.

[9] Avraamides, C.J.; Garmy-Susini, B.; Varner, J.A., Integrins in angiogenesis and lymphangiogenesis. Nat Rev Cancer, 2008, 8 (8), 604-617.

[10] Pierschbacher, M.D.; Ruoslahti, E., Cell attachment activity of fibronectin can be duplicated by small synthetic fragments of the molecule. Nature, 1984, 309 (5963), 30-33.

[11] Ruoslahti, E., The RGD story: a personal account. Matrix Biology, 2003, 22 (6), 459-465.

[12] Pierschbacher, M.D.; Ruoslahti, E., Influence of stereochemistry of the sequence Arg-Gly-Asp-Xaa on binding specificity in cell adhesion. Journal of Biological Chemistry, 1987, 262 (36), 17294-17298.

[13] Danhier, F.; Breton, A.L.; Préat, V., RGD-Based Strategies To Target Alpha(v) Beta(3) Integrin in Cancer Therapy and Diagnosis. Molecular Pharmaceutics, 2012, 9 (11), 2961-2973.

[14] Mina-Osorio, P., The moonlighting enzyme CD13: old and new functions to target. Trends in Molecular Medicine, 2008, 14 (8), $361-371$.

[15] Fukasawa, K.; Fujii, H.; Saitoh, Y.; Koizumi, K.; Aozuka, Y.; Sekine, K.; Yamada, M.; Saiki, I.; Nishikawa, K., Aminopeptidase $\mathrm{N}$ (APN/CD13) is selectively expressed in vascular endothelial cells and plays multiple roles in angiogenesis. Cancer letters, 2006, 243 (1), $135-143$.

[16] Corti, A.; Curnis, F.; Arap, W.; Pasqualini, R., The neovasculature homing motif NGR: more than meets the eye. Blood, 2008, $112(7), 2628-2635$. 
[17] Wickström, M.; Larsson, R.; Nygren, P.; Gullbo, J., Aminopeptidase N (CD13) as a target for cancer chemotherapy. Cancer science, 2011, 102 (3), 501-508.

[18] Curnis, F.; Arrigoni, G.; Sacchi, A.; Fischetti, L.; Arap, W.; Pasqualini, R.; Corti, A., Differential Binding of Drugs Containing the NGR Motif to CD13 Isoforms in Tumor Vessels, Epithelia, and Myeloid Cells. Cancer research, 2002, 62 (3), 867-874.

[19] Toyoda, H.; Komurasaki, T.; Uchida, D.; Takayama, Y.; Isobe , T.; Okuyama , T.; Hanada, K., Epiregulin: a novel epidermal growth factor with mitogenic activity for rat primary hepatocytes. Journal of Biological Chemistry, 1995, 270 (13), $7495-7500$.

[20] Groenen LC, N.E., Burgess AW., Structure-function relationships for the EGF/TGF-alpha family of mitogens

Growth Factors, 1994, 11 (4), 235-257.

[21] Yewale, C.; Baradia, D.; Vhora, I.; Patil, S.; Misra, A., Epidermal growth factor receptor targeting in cancer: A review of trends and strategies. Biomaterials, 2013, 34 (34), 8690-8707.

[22] Song, S.; Liu, D.; Peng, J.; Deng, H.; Guo, Y.; Xu, L.X.; Miller, A.D.; Xu, Y., Novel peptide ligand directs liposomes toward EGF-R high-expressing cancer cells in vitro and in vivo. The FASEB Journal, 2009, 23 (5), 1396-1404.

[23] Schäfer A, P.A., Schaffert D, van Weerden WM, de Ridder CM, Rödl W, Vetter A, Spitzweg C, Kraaij R, Wagner E, Ogris M., Disconnecting the yin and yang relation of epidermal growth factor receptor (EGFR)-mediated delivery: a fully synthetic, EGFR-targeted gene transfer system avoiding receptor activation. Hum Gene Ther, 2011, 22 (12), 1463-1473.

[24] Capello, A.; Krenning, E.P.; Bernard, B.F.; Breeman, W.A.P.; van Hagen, M.P.; de Jong, M., Increased Cell Death After Therapy with an Arg-Gly-Asp-Linked Somatostatin Analog. Journal of Nuclear Medicine, 2004, 45 (10), $1716-1720$.

[25] Zhang, X.; Cai, W.; Cao, F.; Schreibmann, E.; Wu, Y.; Wu, J.C.; Xing, L.; Chen, X., 18F-Labeled Bombesin Analogs for Targeting GRP Receptor-Expressing Prostate Cancer. Journal of Nuclear Medicine, 2006, 47 (3), 492-501.

[26] Stewart, J.M.; Gera, L.; Chan, D.C.; York, E.J.; Simkeviciene, V.; Bunn Jr, P.A.; Taraseviciene-Stewart, L., Combination cancer chemotherapy with one compound: Pluripotent bradykinin antagonists. Peptides, 2005, 26 (8), 1288-1291.

[27] Lam, K.S.; Salmon, S.E.; Hersh, E.M.; Hruby, V.J.; Kazmierski, W.M.; Knapp, R.J., A new type of synthetic peptide library for identifying ligand-binding activity. Nature, 1991, 354 (6348), 82-84.

[28] Lam, K.S.; Lebl, M.; Krchňák, V., The “One-Bead-One-Compound” Combinatorial Library Method. Chemical reviews, 1997, 97 (2), 411-448.

[29] Frank, R., Spot-synthesis: an easy technique for the positionally addressable, parallel chemical synthesis on a membrane support. Tetrahedron, 1992, 48 (42), 9217-9232.

[30] Smith, G.P., Filamentous Fusion Phage: Novel Expression Vectors that Display Cloned Antigens on the Virion Surface. Science, 1985, 228 (4705), 1315-1317.

[31] Krag, D.N.; Shukla, G.S.; Shen, G.-P.; Pero, S.; Ashikaga, T.; Fuller, S.; Weaver, D.L.; Burdette-Radoux, S.; Thomas, C., Selection of Tumor-binding Ligands in Cancer Patients with Phage Display Libraries. Cancer research, 2006, 66 (15), $7724-7733$. 
[32] Samoylova TI, M.N., Globa LP, Cox NR, Peptide phage display: opportunities for development of personalized anti-cancer strategies. Anti-cancer agents in medicinal chemistry, 2006, 6 (1), 9-17.

[33] Lauren RH Krumpe, T.M., Potential of phage-displayed peptide library technology to identify functional targeting peptides. Expert Opin Drug Discov, 2007, 2 (4), 525-537.

[34] Arap, W.; Pasqualini, R.; Ruoslahti, E., Cancer Treatment by Targeted Drug Delivery to Tumor Vasculature in a Mouse Model. Science, 1998, 279 (5349), 377-380.

[35] Aina, O.H.; Liu, R.; Sutcliffe, J.L.; Marik, J.; Pan, C.-X.; Lam, K.S., From Combinatorial Chemistry to Cancer-Targeting Peptides. Molecular Pharmaceutics, 2007, 4 (5), 631-651.

[36] Kappel, J.C.; Fan, Y.C.; Lam, K.S. Valle, S.D.; Escher, E.; Lubell, W.D., Eds.; Springer New York, 2009; Vol. 611, pp 21-22.

[37] Winkler DF, A.H., Hilpert K., SPOT synthesis as a tool to study protein-protein interactions. Methods Mol Biol, 2011, 723 (105-

127.

[38] Ahmed, S.; Mathews, A.S.; Byeon, N.; Lavasanifar, A.; Kaur, K., Peptide Arrays for Screening Cancer Specific Peptides. Analytical chemistry, 2010, 82 (18), 7533-7541.

[39] Soudy, R.; Wang, L.; Kaur, K., Synthetic peptides derived from the sequence of a lasso peptide microcin J25 show antibacterial activity. Bioorganic \&amp; Medicinal Chemistry, 2012, 20 (5), 1794-1800.

[40] Kapoor, P.; Singh, H.; Gautam, A.; Chaudhary, K.; Kumar, R.; Raghava, G.P.S., TumorHoPe: A Database of Tumor Homing Peptides. PloS one, 2012, 7 (4), e35187.

[41] Shadidi, M.; Sioud, M., Selective targeting of cancer cells using synthetic peptides. Drug Resistance Updates, 2003, 6 (6), 363-

371.

[42] Zhang, J.; Spring, H.; Schwab, M., Neuroblastoma tumor cell-binding peptides identified through random peptide phage display. Cancer letters, 2001, 171 (2), 153-164.

[43] Askoxylakis, V.; Mier, W.; Zitzmann, S.; Ehemann, V.; Zhang, J.; Kramer, S.; Beck, C.; Schwab, M.; Eisenhut, M.; Haberkorn, U., Characterization and Development of a Peptide (p160) with Affinity for Neuroblastoma Cells. Journal of nuclear medicine : official publication, Society of Nuclear Medicine, 2006, 47 (6), 981-988.

[44] Soudy, R.; Gill, A.; Sprules, T.; Lavasanifar, A.; Kaur, K., Proteolytically Stable Cancer Targeting Peptides with High Affinity for Breast Cancer Cells. Journal of medicinal chemistry, 2011, 54 (21), 7523-7534.

[45] Sarangthem, V.; Cho, E.A.; Bae, S.M.; Singh, T.D.; Kim, S.J.; Kim, S.; Jeon, W.B.; Lee, B.H.; Park, R.W., Construction and application of elastin like polypeptide containing IL-4 receptor targeting peptide. PloS one, 2013, 8 (12), e81891.

[46] Lu, R.M.; Chen, M.S.; Chang, D.K.; Chiu, C.Y.; Lin, W.C.; Yan, S.L.; Wang, Y.P.; Kuo, Y.S.; Yeh, C.Y.; Lo, A.; Wu, H.C., Targeted drug delivery systems mediated by a novel Peptide in breast cancer therapy and imaging. PloS one, 2013, 8 (6), e66128.

[47] Zitzmann, S.; Mier, W.; Schad, A.; Kinscherf, R.; Askoxylakis, V.; Krämer, S.; Altmann, A.; Eisenhut, M.; Haberkorn, U., A New Prostate Carcinoma Binding Peptide (DUP-1) for Tumor Imaging and Therapy. Clinical Cancer Research, 2005, 11 (1), $139-146$. 

U., Challenges in Optimizing a Prostate Carcinoma Binding Peptide, Identified through the Phage Display Technology. Molecules, 2011, 16 (2), 1559-1578.

[49] Li Z, Z.R., Wu X, Sun Y, Yao M, Li J, Xu Y, Gu J., Identification and characterization of a novel peptide ligand of epidermal growth factor receptor for targeted delivery of therapeutics. FASEB Journal, 2005, 19 (14), 1978-1985.

[50] Du B, Q.M., Zhou Z, Wang P, Wang L, Zhang X, Wu M, Zhang P, Mei B, In vitro panning of a targeting peptide to hepatocarcinoma from a phage display peptide library. Biochem Biophys Res Commun., 2006, 342 (3), $956-962$.

[51] Du, B.; Han, H.; Wang, Z.; Kuang, L.; Wang, L.; Yu, L.; Wu, M.; Zhou, Z.; Qian, M., targeted drug delivery to hepatocarcinoma in vivo by phage-displayed specific binding peptide. Molecular cancer research: MCR, 2010, 8 (2), 135-144.

[52] Tanaka, S.; Pero, S.C.; Taguchi, K.; Shimada, M.; Mori, M.; Krag, D.N.; Arii, S., Specific Peptide Ligand for Grb7 Signal Transduction Protein and Pancreatic Cancer Metastasis. Journal of the National Cancer Institute, 2006, 98 (7), $491-498$.

[53] Pero, S.C.; Oligino, L.; Daly, R.J.; Soden, A.L.; Liu, C.; Roller, P.P.; Li, P.; Krag, D.N., Identification of Novel Nonphosphorylated Ligands, Which Bind Selectively to the SH2 Domain of Grb7. Journal of Biological Chemistry, 2002, 277 (14), 1191811926.

[54] Huang, C.; Liu, X.Y.; Rehemtulla, A.; Lawrence, T.S., Identification of peptides that bind to irradiated pancreatic tumor cells. International journal of radiation oncology, biology, physics, 2005, 62 (5), 1497-1503.

[55] Akita, N.; Maruta, F.; Seymour, L.W.; Kerr, D.J.; Parker, A.L.; Asai, T.; Oku, N.; Nakayama, J.; Miyagawa, S., Identification of oligopeptides binding to peritoneal tumors of gastric cancer. Cancer science, 2006, 97 (10), 1075-1081.

[56] Fukumura, D.; Jain, R.K., Tumor microenvironment abnormalities: Causes, consequences, and strategies to normalize. Journal of cellular biochemistry, 2007, 101 (4), 937-949.

[57] Ruoslahti, E., Vascular zip codes in angiogenesis and metastasis. Biochem. Soc. Trans., 2004, 32 (397-402.

[58] Boehm, T.; Folkman, J.; Browder, T.; O'Reilly, M.S., Antiangiogenic therapy of experimental cancer does not induce acquired drug resistance. Nature, 1997, 390 (6658), 404-407.

[59] Browder, T.; Butterfield, C.E.; Kräling, B.M.; Shi, B.; Marshall, B.; O’Reilly, M.S.; Folkman, J., Antiangiogenic Scheduling of Chemotherapy Improves Efficacy against Experimental Drug-resistant Cancer. Cancer research, 2000, 60 (7), $1878-1886$.

[60] Pasqualini, R.; Koivunen, E.; Ruoslahti, E., [alpha]v Integrins as receptors for tumor targeting by circulating ligands. Nat Biotech, 1997, 15 (6), 542-546.

[61] Koivunen, E.; Gay, D.A.; Ruoslahti, E., Selection of peptides binding to the alpha 5 beta 1 integrin from phage display library. Journal of Biological Chemistry, 1993, 268 (27), 20205-20210.

[62] Koivunen E, W.B., Ruoslahti E., Phage libraries displaying cyclic peptides with different ring sizes: ligand specificities of the RGD-directed integrins. Biotechnology (N Y), 1995, 13 (3), 265-270. 
[63] Maubant, S.; Saint-Dizier, D.; Boutillon, M.; Perron-Sierra, F.; Casara, P.J.; Hickman, J.A.; Tucker, G.C.; Van ObberghenSchilling, E., Blockade of $\alpha v \beta 3$ and $\alpha v \beta 5$ integrins by RGD mimetics induces anoikis and not integrin-mediated death in human endothelial cells. Blood, 2006, 108 (9), 3035-3044.

[64] Dickerson, E.B.; Akhtar, N.; Steinberg, H.; Wang, Z.-Y.; Lindstrom, M.J.; Padilla, M.L.; Auerbach, R.; Helfand, S.C., Enhancement of the Antiangiogenic Activity of Interleukin-12 by Peptide Targeted Delivery of the Cytokine to av $\beta 3$ Integrin. Molecular Cancer Research, 2004, 2 (12), 663-673.

[65] Mas-Moruno, C.; Rechenmacher, F.; Kessler, H., Cilengitide: The first anti-angiogenic small molecule drug candidate. Design, synthesis and clinical evaluation. Anticancer Agents Med. Chem., 2010, 10 (10), 753-768.

[66] Chinot, O.L., Cilengitide in glioblastoma: when did it fail? The Lancet Oncology, 2014, 15 (10), $1044-1045$.

[67] Xiong JP, S.T., Zhang R, Joachimiak A, Frech M, Goodman SL, Arnaout MA., Crystal structure of the extracellular segment of integrin alpha Vbeta3 in complex with an Arg-Gly-Asp ligand. Science, 2002, 296 (5565), 151-155.

[68] Haubner, R.; Gratias, R.; Diefenbach, B.; Goodman, S.L.; Jonczyk, A.; Kessler, H., Structural and Functional Aspects of RGDContaining Cyclic Pentapeptides as Highly Potent and Selective Integrin $\alpha \mathrm{V} \beta 3$ Antagonists. Journal of the American Chemical Society, 1996, 118 (32), 7461-7472.

[69] Liu, S., Radiolabeled Multimeric Cyclic RGD Peptides as Integrin av $\beta 3$ Targeted Radiotracers for Tumor Imaging. Molecular Pharmaceutics, 2006, 3 (5), 472-487.

[70] Li, Z.-b.; Cai, W.; Cao, Q.; Chen, K.; Wu, Z.; He, L.; Chen, X., 64Cu-Labeled Tetrameric and Octameric RGD Peptides for Small-Animal PET of Tumor $\alpha v \beta 3$ Integrin Expression. Journal of Nuclear Medicine, 2007, 48 (7), 1162-1171.

[71] Mammen M, C.S.-K., Whitesides GM. , Polyvalent Interactions in Biological Systems: Implications for Design and Use of Multivalent Ligands and Inhibitors. Angew. Chem. , 1998, 37 (20), 2754-2794.

[72] Kubas, H.; Schäfer, M.; Bauder-Wüst, U.; Eder, M.; Oltmanns, D.; Haberkorn, U.; Mier, W.; Eisenhut, M., Multivalent cyclic RGD ligands: influence of linker lengths on receptor binding. Nuclear medicine and biology, 2010, 37 (8), 885-891.

[73] Boturyn, D.; Coll, J.-L.; Garanger, E.; Favrot, M.-C.; Dumy, P., Template Assembled Cyclopeptides as Multimeric System for Integrin Targeting and Endocytosis. Journal of the American Chemical Society, 2004, 126 (18), 5730-5739.

[74] Falciani, C.; Pini, A.; Bracci, L., Oligo-branched peptides for tumor targeting: from magic bullets to magic forks. Expert opinion on biological therapy, 2009, 9 (2), 171-178.

[75] Teesalu, T.; Sugahara, K.N.; Kotamraju, V.R.; Ruoslahti, E., C-end rule peptides mediate neuropilin-1-dependent cell, vascular, and tissue penetration. Proceedings of the National Academy of Sciences, 2009, 106 (38), 16157-16162.

[76] Teesalu, T.; Sugahara, K.N.; Ruoslahti, E., Tumor penetrating peptides. Frontiers in oncology, 2013, 3 (

[77] Mamluk, R.; Klagsbrun, M.; Detmar, M.; Bielenberg, D., Soluble neuropilin targeted to the skin inhibits vascular permeability. Angiogenesis, 2005, 8 (3), 217-227. 

S.A., Vascular endothelial growth factor (VEGF)-like protein from orf virus NZ2 binds to VEGFR2 and neuropilin-1. Proceedings of the National Academy of Sciences of the United States of America, 1999, 96 (6), 3071-3076.

[79] Sugahara, K.N.; Teesalu, T.; Karmali, P.P.; Kotamraju, V.R.; Agemy, L.; Greenwald, D.R.; Ruoslahti, E., Coadministration of a Tumor-Penetrating Peptide Enhances the Efficacy of Cancer Drugs. Science, 2010, 328 (5981), 1031-1035.

[80] van Hensbergen, Y.; Broxterman, H.J.; Elderkamp, Y.W.; Lankelma, J.; Beers, J.C.C.; Heijn, M.; Boven, E.; Hoekman, K.; Pinedo, H.M., A doxorubicin-CNGRC-peptide conjugate with prodrug properties. Biochemical pharmacology, 2002, 63 (5), 897-908.

[81] Ndinguri, M.W.; Solipuram, R.; Gambrell, R.P.; Aggarwal, S.; Hammer, R.P., Peptide Targeting of Platinum Anti-Cancer Drugs. Bioconjugate chemistry, 2009, 20 (10), 1869-1878.

[82] Ellerby, H.M.; Arap, W.; Ellerby, L.M.; Kain, R.; Andrusiak, R.; Rio, G.D.; Krajewski, S.; Lombardo, C.R.; Rao, R.; Ruoslahti, E.; Bredesen, D.E.; Pasqualini, R., Anti-cancer activity of targeted pro-apoptotic peptides. Nature medicine, 1999, 5 (9), $1032-1038$.

[83] Curnis, F.; Sacchi, A.; Borgna, L.; Magni, F.; Gasparri, A.; Corti, A., Enhancement of tumor necrosis factor [alpha] antitumor immunotherapeutic properties by targeted delivery to aminopeptidase N (CD13). Nat Biotech, 2000, 18 (11), 1185-1190.

[84] Santoro, A.; Pressiani, T.; Citterio, G.; Rossoni, G.; Donadoni, G.; Pozzi, F.; Rimassa, L.; Personeni, N.; Bozzarelli, S.; Colombi, S.; De Braud, F.G.; Caligaris-Cappio, F.; Lambiase, A.; Bordignon, C., Activity and safety of NGR-hTNF, a selective vasculartargeting agent, in previously treated patients with advanced hepatocellular carcinoma. British journal of cancer, 2010, 103 (6), 837-844.

[85] Santoro, A.; Rimassa, L.; Sobrero, A.F.; Citterio, G.; Sclafani, F.; Carnaghi, C.; Pessino, A.; Caprioni, F.; Andretta, V.; Tronconi, M.C.; Finocchiaro, G.; Rossoni, G.; Zanoni, A.; Miggiano, C.; Rizzardi, G.-P.; Traversari, C.; Caligaris-Cappio, F.; Lambiase, A.; Bordignon, C., Phase II study of NGR-hTNF, a selective vascular targeting agent, in patients with metastatic colorectal cancer after failure of standard therapy. European Journal of Cancer, 2010, 46 (15), 2746-2752.

[86] Negussie, A.H.; Miller, J.L.; Reddy, G.; Drake, S.K.; Wood, B.J.; Dreher, M.R., Synthesis and in vitro evaluation of cyclic NGR peptide targeted thermally sensitive liposome. Journal of Controlled Release, 2010, 143 (2), 265-273.

[87] Metaferia, B.B.; Rittler, M.; Gheeya, J.S.; Lee, A.; Hempel, H.; Plaza, A.; Stetler-Stevenson, W.G.; Bewley, C.A.; Khan, J., Synthesis of novel cyclic NGR/RGD peptide analogs via on resin click chemistry. Bioorganic \&amp; Medicinal Chemistry Letters, 2010, 20 (24), 7337-7340.

[88] Colombo, G.; Curnis, F.; De Mori, G.M.S.; Gasparri, A.; Longoni, C.; Sacchi, A.; Longhi, R.; Corti, A., Structure-Activity Relationships of Linear and Cyclic Peptides Containing the NGR Tumor-homing Motif. Journal of Biological Chemistry, 2002, 277 (49), 47891-47897.

[89] Plesniak, L.A.; Salzameda, B.; Hinderberger, H.; Regan, E.; Kahn, J.; Mills, S.A.; Teriete, P.; Yao, Y.; Jennings, P.; Marassi, F.; Adams, J.A., Structure and Activity of CPNGRC: A Modified CD13/APN Peptidic Homing Motif. Chemical biology \& drug design, 2010, 75 (6), 551-562. 
[90] Curnis, F.; Longhi, R.; Crippa, L.; Cattaneo, A.; Dondossola, E.; Bachi, A.; Corti, A., Spontaneous Formation of L-Isoaspartate and Gain of Function in Fibronectin. Journal of Biological Chemistry, 2006, 281 (47), 36466-36476.

[91] Curnis, F.; Cattaneo, A.; Longhi, R.; Sacchi, A.; Gasparri, A.M.; Pastorino, F.; Di Matteo, P.; Traversari, C.; Bachi, A.; Ponzoni, M.; Rizzardi, G.-P.; Corti, A., Critical Role of Flanking Residues in NGR-to-isoDGR Transition and CD13/Integrin Receptor Switching. Journal of Biological Chemistry, 2010, 285 (12), 9114-9123.

[92] Soudy, R.; Ahmed, S.; Kaur, K., NGR Peptide Ligands for Targeting CD13/APN Identified through Peptide Array Screening Resemble Fibronectin Sequences. ACS Combinatorial Science, 2012.

[93] Laakkonen, P.; Åkerman, M.E.; Biliran, H.; Yang, M.; Ferrer, F.; Karpanen, T.; Hoffman, R.M.; Ruoslahti, E., Antitumor activity of a homing peptide that targets tumor lymphatics and tumor cells. Proceedings of the National Academy of Sciences of the United States of America, 2004, 101 (25), 9381-9386.

[94] Laakkonen, P.; Zhang, L.; Ruoslahti, E., Peptide Targeting of Tumor Lymph Vessels. Annals of the New York Academy of Sciences, 2008, 1131 (1), 37-43.

[95] Laakkonen, P.; Porkka, K.; Hoffman, J.A.; Ruoslahti, E., A tumor-homing peptide with a targeting specificity related to lymphatic vessels. Nature medicine, 2002, 8 (7), 751-755.

[96] Fogal, V.; Zhang, L.; Krajewski, S.; Ruoslahti, E., Mitochondrial/Cell-Surface Protein p32/gC1qR as a Molecular Target in Tumor Cells and Tumor Stroma. Cancer research, 2008, 68 (17), 7210-7218.

[97] Witt, H.; Hajdin, K.; Iljin, K.; Greiner, O.; Niggli, F.K.; Schäfer, B.W.; Bernasconi, M., Identification of a rhabdomyosarcoma targeting peptide by phage display with sequence similarities to the tumour lymphatic-homing peptide LyP-1. International Journal of Cancer, 2009, 124 (9), 2026-2032.

[98] Zhang, L.; Giraudo, E.; Hoffman, J.A.; Hanahan, D.; Ruoslahti, E., Lymphatic Zip Codes in Premalignant Lesions and Tumors. Cancer research, 2006, 66 (11), 5696-5706.

[99] Ruoslahti, E.; Bhatia, S.N.; Sailor, M.J., Targeting of drugs and nanoparticles to tumors. The Journal of cell biology, 2010, 188 (6), 759-768.

[100] Bertrand, N.; Wu, J.; Xu, X.; Kamaly, N.; Farokhzad, O.C., Cancer nanotechnology: the impact of passive and active targeting in the era of modern cancer biology. Advanced drug delivery reviews, 2014, 66 (2-25.

[101] Laakkonen, P.; Vuorinen, K., Homing peptides as targeted delivery vehicles. Integrative Biology, 2010, 2 (7-8), $326-337$.

[102] Nagy, A.; Schally, A.V.; Armatis, P.; Szepeshazi, K.; Halmos, G.; Kovacs, M.; Zarandi, M.; Groot, K.; Miyazaki, M.; Jungwirth, A.; Horvath, J., Cytotoxic analogs of luteinizing hormone-releasing hormone containing doxorubicin or 2-pyrrolinodoxorubicin, a derivative 500-1000 times more potent. Proceedings of the National Academy of Sciences, 1996, 93 (14), 7269-7273.

[103] Kurzrock, R.; Gabrail, N.; Chandhasin, C.; Moulder, S.; Smith, C.; Brenner, A.; Sankhala, K.; Mita, A.; Elian, K.; Bouchard, D.; Sarantopoulos, J., Safety, Pharmacokinetics, and Activity of GRN1005, a Novel Conjugate of Angiopep-2, a Peptide Facilitating Brain Penetration, and Paclitaxel, in Patients with Advanced Solid Tumors. Molecular cancer therapeutics, 2012, 11 (2), $308-316$. 
[104] Soudy, R.; Chen, C.; Kaur, K., Novel Peptide-Doxorubucin Conjugates for Targeting Breast Cancer Cells Including the Multidrug Resistant Cells. Journal of medicinal chemistry, 2013, 56 (19), 7564-7573.

[105] Callahan, R., Ado-Trastuzumab Emtansine in Metastatic HER2-Positive Breast Cancer. Journal of the advanced practitioner in oncology, 2014, 5 (2), 134-139.

[106] Matsui, H.; Takeshita, A.; Naito, K.; Shinjo, K.; Shigeno, K.; Maekawa, M.; Yamakawa, Y.; Tanimoto, M.; Kobayashi, M.; Ohnishi, K.; Ohno, R., Reduced effect of gemtuzumab ozogamicin (CMA-676) on P-glycoprotein and/or CD34-positive leukemia cells and its restoration by multidrug resistance modifiers. Leukemia, 2002, 16 (5), 813-819.

[107] Takeshita, A.; Shinjo, K.; Yamakage, N.; Ono, T.; Hirano, I.; Matsui, H.; Shigeno, K.; Nakamura, S.; Tobita, T.; Maekawa, M.; Ohnishi, K.; Sugimoto, Y.; Kiyoi, H.; Naoe, T.; Ohno, R., CMC-544 (inotuzumab ozogamicin) shows less effect on multidrug resistant cells: analyses in cell lines and cells from patients with B-cell chronic lymphocytic leukaemia and lymphoma. British Journal of Haematology, 2009, $146(1), 34-43$.

[108] Kovtun, Y.V.; Audette, C.A.; Mayo, M.F.; Jones, G.E.; Doherty, H.; Maloney, E.K.; Erickson, H.K.; Sun, X.; Wilhelm, S.; Ab, O.; Lai, K.C.; Widdison, W.C.; Kellogg, B.; Johnson, H.; Pinkas, J.; Lutz, R.J.; Singh, R.; Goldmacher, V.S.; Chari, R.V.J., AntibodyMaytansinoid Conjugates Designed to Bypass Multidrug Resistance. Cancer research, 2010, 70 (6), 2528-2537.

[109] Yu, B.; Tai, H.C.; Xue, W.; Lee, L.J.; Lee, R.J., Receptor-targeted nanocarriers for therapeutic delivery to cancer. Molecular membrane biology, 2010, 27 (7), 286-298.

[110] Pearce, T.R.; Shroff, K.; Kokkoli, E., Peptide Targeted Lipid Nanoparticles for Anticancer Drug Delivery. Advanced Materials, 2012, 24 (28), 3803-3822.

[111] Xiong, X.-B.; Ma, Z.; Lai, R.; Lavasanifar, A., The therapeutic response to multifunctional polymeric nano-conjugates in the targeted cellular and subcellular delivery of doxorubicin. Biomaterials, 2010, 31 (4), 757-768.

[112] Pastorino, F.; Brignole, C.; Di Paolo, D.; Nico, B.; Pezzolo, A.; Marimpietri, D.; Pagnan, G.; Piccardi, F.; Cilli, M.; Longhi, R.; Ribatti, D.; Corti, A.; Allen, T.M.; Ponzoni, M., Targeting Liposomal Chemotherapy via Both Tumor Cell-Specific and Tumor Vasculature-Specific Ligands Potentiates Therapeutic Efficacy. Cancer research, 2006, 66 (20), 10073-10082.

[113] Shahin, M.; Ahmed, S.; Kaur, K.; Lavasanifar, A., Decoration of polymeric micelles with cancer-specific peptide ligands for active targeting of paclitaxel. Biomaterials, 2011, 32 (22), 5123-5133.

[114] Shahin, M.; Soudy, R.; El-Sikhry, H.; Seubert, J.M.; Kaur, K.; Lavasanifar, A., Engineered peptides for the development of actively tumor targeted liposomal carriers of doxorubicin. Cancer letters, 2012.

[115] Shahin, M.; Soudy, R.; Aliabadi, H.M.; Kneteman, N.; Kaur, K.; Lavasanifar, A., Engineered breast tumor targeting peptide ligand modified liposomal doxorubicin and the effect of peptide density on anticancer activity. Biomaterials, 2013, 34 (16), $4089-4097$.

[116] Heppeler, A.; Froidevaux, S.; Eberle, A.N.; Maecke, H.R., Receptor Targeting for Tumor Localisation and Therapy with Radiopeptides. Current medicinal chemistry, 2000, 7 (9), 971-994. 
[117] Åkerman, M.E.; Chan, W.C.W.; Laakkonen, P.; Bhatia, S.N.; Ruoslahti, E., Nanocrystal targeting in vivo. Proceedings of the National Academy of Sciences, 2002, 99 (20), 12617-12621.

[118] Rufini, V.; Calcagni, M.L.; Baum, R.P., Imaging of Neuroendocrine Tumors. Seminars in nuclear medicine, 2006, 36 (3), 228247.

[119] Scopinaro, F.; Vincentis, G.; Varvarigou, A.; Laurenti, C.; Iori, F.; Remediani, S.; Chiarini, S.; Stella, S., 99mTc-bombesin detects prostate cancer and invasion of pelvic lymph nodes. European journal of nuclear medicine and molecular imaging, 2003, 30 (10), 1378-1382.

[120] Fani, M.; Maecke, H.R.; Okarvi, S.M., Radiolabeled peptides: valuable tools for the detection and treatment of cancer. Theranostics, 2012, 2 (5), 481-501.

[121] Lee, H.-Y.; Li, Z.; Chen, K.; Hsu, A.R.; Xu, C.; Xie, J.; Sun, S.; Chen, X., PET/MRI Dual-Modality Tumor Imaging Using Arginine-Glycine-Aspartic (RGD)-Conjugated Radiolabeled Iron Oxide Nanoparticles. Journal of Nuclear Medicine, 2008, 49 (8), 13711379.

[122] Mulder, W.J.M.; Strijkers, G.J.; Habets, J.W.; Bleeker, E.J.W.; van der Schaft, D.W.J.; Storm, G.; Koning, G.A.; Griffioen, A.W.; Nicolay, K., MR molecular imaging and fluorescence microscopy for identification of activated tumor endothelium using a bimodal lipidic nanoparticle. The FASEB Journal, 2005, 19 (14), 2008-2010.

[123] Zhou, Y.; Chakraborty, S.; Liu, S., Radiolabeled Cyclic RGD Peptides as Radiotracers for Imaging Tumors and Thrombosis by SPECT. Theranostics, 2011, 1 (58-82.

[124] Buehler, A.; van Zandvoort, M.A.M.J.; Stelt, B.J.; Hackeng, T.M.; Schrans-Stassen, B.H.G.J.; Bennaghmouch, A.; Hofstra, L.; Cleutjens, J.P.M.; Duijvestijn, A.; Smeets, M.B.; de Kleijn, D.P.V.; Post, M.J.; de Muinck, E.D., cNGR: A Novel Homing Sequence for CD13/APN Targeted Molecular Imaging of Murine Cardiac Angiogenesis In Vivo. Arteriosclerosis, thrombosis, and vascular biology, 2006, 26 (12), 2681-2687.

[125] Liu, P.; Qin, L.; Wang, Q.; Sun, Y.; Zhu, M.; Shen, M.; Duan, Y., cRGD-functionalized mPEG-PLGA-PLL nanoparticles for imaging and therapy of breast cancer. Biomaterials, 2012, 33 (28), 6739-6747.

[126] Yin, P.; Wang, Y.; Qiu, Y.; Hou, L.; Liu, X.; Qin, J.; Duan, Y.; Liu, P.; Qiu, M.; Li, Q., Bufalin-loaded mPEG-PLGA-PLLcRGD nanoparticles: preparation, cellular uptake, tissue distribution, and anticancer activity. International journal of nanomedicine, 2012, 7 (3961-3969.

[127] Miura, Y.; Takenaka, T.; Toh, K.; Wu, S.; Nishihara, H.; Kano, M.R.; Ino, Y.; Nomoto, T.; Matsumoto, Y.; Koyama, H.; Cabral, H.; Nishiyama, N.; Kataoka, K., Cyclic RGD-Linked Polymeric Micelles for Targeted Delivery of Platinum Anticancer Drugs to Glioblastoma through the Blood-Brain Tumor Barrier. ACS Nano, 2013, 7 (10), 8583-8592.

[128] Chen, Z.; Deng, J.; Zhao, Y.; Tao, T., Cyclic RGD peptide-modified liposomal drug delivery system: enhanced cellular uptake in vitro and improved pharmacokinetics in rats. International journal of nanomedicine, 2012, 7 (3803-3811. 
[129] Luo, L.-M.; Huang, Y.; Zhao, B.-X.; Zhao, X.; Duan, Y.; Du, R.; Yu, K.-F.; Song, P.; Zhao, Y.; Zhang, X.; Zhang, Q., Antitumor and anti-angiogenic effect of metronomic cyclic NGR-modified liposomes containing paclitaxel. Biomaterials, 2013, 34 (4), 11021114.

[130] Zhao, B.-J.; Ke, X.-Y.; Huang, Y.; Chen, X.-M.; Zhao, X.; Zhao, B.-X.; Lu, W.-1.; Lou, J.-N.; Zhang, X.; Zhang, Q., The antiangiogenic efficacy of NGR-modified PEG-DSPE micelles containing paclitaxel (NGR-M-PTX) for the treatment of glioma in rats. Journal of Drug Targeting, 2011, 19 (5), 382-390.

[131] Notni, J.; Pohle, K.; Wester, H.-J., Be spoilt for choice with radiolabelled RGD peptides: Preclinical evaluation of 68GaTRAP(RGD)3. Nuclear medicine and biology, 2013, 40 (1), 33-41.

[132] Yang, J.; Luo, Y.; Xu, Y.; Li, J.; Zhang, Z.; Wang, H.; Shen, M.; Shi, X.; Zhang, G., Conjugation of Iron Oxide Nanoparticles with RGD-Modified Dendrimers for Targeted Tumor MR Imaging. ACS applied materials \& interfaces, 2015, 7 (9), $5420-5428$.

[133] Šimeček, J.; Notni, J.; Kapp, T.G.; Kessler, H.; Wester, H.-J., Benefits of NOPO As Chelator in Gallium-68 Peptides, Exemplified by Preclinical Characterization of 68Ga-NOPO-c(RGDfK). Molecular Pharmaceutics, 2014,11 (5), $1687-1695$.

[134] Sun, X.; Huang, X.; Yan, X.; Wang, Y.; Guo, J.; Jacobson, O.; Liu, D.; Szajek, L.P.; Zhu, W.; Niu, G.; Kiesewetter, D.O.; Sun, S.; Chen, X., Chelator-Free 64Cu-Integrated Gold Nanomaterials for Positron Emission Tomography Imaging Guided Photothermal Cancer Therapy. ACS Nano, 2014, 8 (8), 8438-8446.

[135] Maschauer, S.; Haubner, R.; Kuwert, T.; Prante, O., 18F-Glyco-RGD Peptides for PET Imaging of Integrin Expression: Efficient Radiosynthesis by Click Chemistry and Modulation of Biodistribution by Glycosylation. Molecular Pharmaceutics, 2014,11 (2), $505-515$.

[136] Chen, K.; Ma, W.; Li, G.; Wang, J.; Yang, W.; Yap, L.-P.; Hughes, L.D.; Park, R.; Conti, P.S., Synthesis and Evaluation of 64Cu-Labeled Monomeric and Dimeric NGR Peptides for MicroPET Imaging of CD13 Receptor Expression. Molecular Pharmaceutics, 2013, 10 (1), 417-427.

[137] Máté, G.; Kertész, I.; Enyedi, K.N.; Mező, G.; Angyal, J.; Vasas, N.; Kis, A.; Szabó, É.; Emri, M.; Bíró, T.; Galuska, L.; Trencsényi, G., In vivo imaging of Aminopeptidase N (CD13) receptors in experimental renal tumors using the novel radiotracer 68GaNOTA-c(NGR). European Journal of Pharmaceutical Sciences, 2015, 69 (0), 61-71. 